\title{
Partial-Industry Regulation: A Monopsony Standard for Consumer Protection
}

\author{
Ian Ayres $\uparrow$ and John Braithwaite
}

Regulations usually apply to all members of an industry. Professors Ayres and Braithwaite propose that in some situations "partial industry" regulation is superior to all-or-nothing regulatory policies. Partial-industry regulation governs only a part of an industry, leaving other parts either unregulated or disparately regulated. Regulating only an individual firm (or subset of firms) can engender a system of checks and balances in which the regulated and unregulated portions of the market each curb the excesses of the alternative form of market governance. Partial-industry regulation can thus promote efficiency by restraining monopoly power without giving rise to the evils of either captured or benighted regulation. The authors' theories of partial-industry intervention gain support from an analysis of monopsonist behavior. Governments interested in promoting consumer welfare should often emulate what a monopsonist consumer would do. One way to reconceive of the regulator's decision whether to subsidize fringe competition is to ask if a hypothetical downstream monopsonist would subsidize upstream entry to "second-source" the product. A monopsony standard provides not only a powerful tool for analyzing how government might intervene to protect consumers, but also a limiting principle for analyzing when intervention is appropriate.

\section{INTRODUCTION}

Federal and state regulation of the United States econoniy often displays an all-or-nothing character: regulations govern either all nienibers of an industry or none. A host of federal agencies pervasively regulate the conduct of entire industries. For exaniple, the Securities and Exchange Commission regulates the securities industry, the Food and

$\dagger$ Professor of Law, Stanford Law School; Research Fellow, American Bar Foundation. B.A. 1981, J.D. 1986, Yale University; Ph.D. 1988, Massachusetts Institute of Technology.

$\ddagger$ Professorial Fellow, Australian National University. B.A. 1972, Ph.D. 1977, Queensland University.

We would like to thank Ken Abbott, Geoffrey Brennan, John Clifford, John Donohue, Meyer Freed, Barbara Glenn, Bob Goodin, Peter Grabosky, Fred Gruen, David Haddocik, Peter Siegelnian, and participants at a Law and Society Association presentation for their comments. Research support of the American Bar Foundation is gratefully acknowledged. 
Drug Administration regulates the production of pharmaceuticals, and the Federal Reserve regulates the banking industry. In addition, many regulations proinulgated under federal statutes, such as the Clean Air Act, inandate or prescribe certain dimensions of industry behavior. Even a1nong industries that are not extensively regulated, those regulations that do exist tend to apply to all imdustry inembers or none.

Not surprisingly, the academic and political discussion of regulation mirrors this dichotonous reality. The deregulation debate often implicitly considers only two regulatory alternatives: government inust either mipose industry-wide regulations or allow unconstrained markets to determine the allocation of scarce resources. The regulatory literature has identified significant costs associated with each alternative. Laissezfaire policies that leave inonopoly or oligopoly power unchecked in private hands might allow imdustry nneinbers to raise their prices above the coinpetitive level. ${ }^{1}$ But industry-wide regulation inight have the same effect: regulators can be "captured" by the very firms they attempt to regulate. ${ }^{2}$ Captured regulators can organize a cartel ainong producers in an industry and legally inandate that these firms sell at an inflated price. For those who fear these costs of capture, the only thing worse than lettimg market power coalesce in private hands is giving a corrupt Leviathan the power to define the parameters of market transactions.

Even uncaptured regulators face siguificant imformational hurdles in promulgatimg efficient regulations. Regulatory agencies may have great difficulty ascertaining the proper "coinpetitive" price because production costs are not observable. If the agency guesses too low, firms will not recoup their costs; if the agency guesses too high, consumers again will be forced to buy at cartel-like prices.

This Article explores a middle path between the Scylla of full industry regulation and the Charybdis of laissez-faire policies. We propose that in soine situations "partial-industry" regulation may be superior to all-or-nothing regulatory pohcies. In its broadest sense a regime of partial-industry regulation would allow a government to regulate only part of an industry, leaving the rest unregulated. ${ }^{3}$ Under partial-industry reg-

1. See Joe S. Bain, Industrial ORGanization 25-36 (1959) (discussing pricing theory and effects of seller concentration on firm conduct and performance).

2. See Gary S. Becker, A Theory of Competition Among Pressure Groups for Political Influence, 98 Q.J. Econ. 371 (1983) (presenting a theory of competition amoug pressure groups for political influence); Sam Peltzman, Toward a More General Theory of Regulation, 19 J.L. \& EcoN. 211 (1976) (elaborating on the theory that returns from group capture of regulators diminish as group size increases); George J. Stigler, The Theory of Economic Regulation, 2 BELL J. ECON. \& MGMT. 3, 10-12 (1971) (discussing industry ability to employ political machinery to their own ends).

3. Thus, a broad reading of partial-industry regulation would encompass regulatory regimes that disparately affect members within the same industry. Such a situation exists in the United States both in the securities industry, in that equivalent securities face differential regulation by the Securities and Exchange Commission and the Commodity Futures Trading Commission, and in the 
ulatory schemes, government purposefully treats firms in an industry differently. ${ }^{4}$

In some regulatory settimgs, regulating only an individual firm (or a subset of the firms) in an industry can promote efficiency by restraining monopoly power without giving rise to the evils of either captured or benighted regulation. Especially in a dynamic or evolutionary sense, partial-industry regulation might be more resihent to private and public abuses of inarket power. Our theory derives its strengtli from botl1 camps of the regulation/deregulation debate. Like advocates of regulation, we accept that unregulated markets sometimes fail to produce coinpetitive prices. But like advocates of deregulation, we also acknowledge that unregulated competitors have strong incentives to chisel away at cartel agreements and thereby destabilize collusion. Unlike full-industry regulation, which extinguishes many benefits of interfirm competition, ${ }^{5}$ partial-industry regulatory strategies try to harness and foster the welfare-enhancing effects of competition.

Partial-industry regulation beguis with the premise that the existence of a simgle or a few coinpetitive firms can dramatically affect the coinpetitive conduct and performance of an entire mdustry. The central insight of partial-industry regulation is that government can accoinplish many regulatory goals by maintaining the competitive performance of a subset of the firms in an industry. Far from denying the powerful effect of coinpetition, partial-industry regulation uses the regulated firms to affect the behavior of other firms in the market. Unlike across-the-board industry regulation, lowever, mistaken or captured government deci-

dairy market, in which regulation sets different minimum prices for milk producers in different states. Different levels of judicial or agency scrutiny, including disparate efforts to detect noncompliance, would also create a partial-industry regulatory dynamic in that some firms would effectively be less regulated.

Partial-industry regulation could be especially important in interuational markets, in which this idea intersects with the current "industrial policy" debate-concerning whether and how to promote doinestic industries. In iuternational inarkets many foreign coinpetitors are beyond the reach of an individual governinent's fiat, so partial-industry regnlation could in effect be the only regulatory alternative. As discussed below, see infra notes 39-44 and accoinpanying text, the partial-industry goal of assuring sccond sources of supply could be especially important to consumers in general. But in the interuational context individual states are likely to prefer expanding their local production over the improveinent of global social welfare.

4. Most of the regulations discussed in this Article will be "innunutable" in the sense that affected firms will not have the option of contracting around them. See generally Ian Ayres \& Robert Gertner, Filling Gaps in Incomplete Contracts: An Economic Theory of Default Rules, 99 YALE L.J. 87, 87-91 (1989) (providing an overview of immutable rules). There will be settings in which unregulated firms will be able to opt into the regulations, however, such as by contractually committing to sell at the regulated price.

5. For example, when the United States Civil Aeronautics Board set airline fares, airlines by law could not coinpete over price, and were left to compete on such nonprice dinensions of airline service as nonstop flights and on-time performance. The result benefitted neither the airlines nor consumers. See Richard A. Posner, Economic ANal.ysis of Law 204 (2d ed. 1977). 
sions do not necessarily adversely affect the unregulated firms. Instead of completely displacmg the market, partial-industry regulation maintains a structure of "checks and balances" between the two extremes of regulation.

Partial-industry regulation can be seen as a form of regulatory delegation. ${ }^{6}$ The regulated firms in the industry indirectly bear the burden of assuring that the unregulated firms coinply. The coinpliance of unregulated firms is assured because competition forces thein to match the offers of the regulated firm. Therefore, unlike other strategies of delegation, the regulated firms do not need to appreciate their disciplining function.

A inajor thesis of this Article is that government should adopt a "monopsony standard" for consuiner protection interventions. Under this standard, government should only intervene on consumers' behalf to improve the workings of a inarket in situations where a monopsonist buyer $^{7}$ would rationally intervene on its own behalf. The monopsony standard provides strong indications of when and how government should intervene. Monopsonists represent the quintessentially empowered consumer. By studying how these consuniers with market power protect theniselves, government can better target and tailor interventions on behalf of less powerful consumers. We argue that a monopsony standard provides particularly strong evidence supporting the use of partialindustry regulation because inonopsonists often undertake their own private analogues to partial-industry interventions. ${ }^{8}$

A monopsony standard for consunier protection is also attractive because it provides a limiting principle nidicating when governnent should intervene. As discussed below, ${ }^{9}$ the private practice of secondsourcing-subsidizing second sources of supply-shows that treating sellers differently can indeed be rational in individual cases, and provides

6. In a separate work we place partial-industry regulation in a broader framework of regulatory delegation. See IAN AYRES \& JOHN BRAITHWAITE, Responsive Regulation: TRANSCENDING THE DEREgulation DeBATE (forthcoming 1992). In that book we also discuss how regulatory enforcement might also be delegated to third parties ("tripartism") or to the regulated firms themselves ("enforced self-regulation"). For a brief discussion of tripartite interventionism, see the Conclusion of this Article.

7. In a market in which there is a single buyer, that buyer is defined as a monopsonist.

8. This monopsony standard could be used to inform other aspects of consumer protection. For example, the tendency of monopsonists to require sellers to diselose their markup provides strong evidence that markup disclosure might promote the welfare of more diffuse groups of consumers. See Ian Ayres \& F. Clayton Miller, "I'll Sell It To You At Cost": Legal Methods to Promote Retail Markup Disclosure, 84 Nw. U. L. REV. 1047, 1057 (1990) (noting that some monopsonists bargain for markup disclosure). The tendency of multiple-car buyers to negotiate fixed prices provides evidence that intervention to reduce price dispersion might promote consumer welfare. See Ian Ayres, Fair Driving: Gender and Race Discrimination in Retail Car Negotiations, 104 HARV. L. REV. 817, 868-71 (1991) (discussing reform strategies of prohibiting high markup sales, restricting price dispersion, and mandating disclosure of markups to protect consumers).

9. See infra notes $40-44$ and accompanying text. 
government with guidelines for distinguishing situations in which government-sanctioned disparate treatment is likely to be rational from situations in which it is not. The monopsony standard thus provides a powerful source of necessary (but not sufficient) conditions for intervention. Even when a monopsomist would intervene, the particular costs of government intervention might preclude the use of partial-industry regulation. Thus, the monopsony standard inore concretely provides a limiting principle to government actions, suggestimg that if a inonopsonist would not intervene to change a market outcome, government should not either.

Froin the prevailing all-or-nothing regulatory mind-set, many forıns of partial-industry regulation might seein radical. This Article provides a theoretical justification for further exploration of partial-mdustry regulation, bolstering its thesis with examples of successful private and public interventions that disparately regulate the sellers im particular markets. For the most part we argue for government regulatory atteinpts that promote coinpetitive pricing in industries. But our larger arguinent is that partial-industry regulation can be a useful policy tool to correct other types of market failure as well. ${ }^{10}$ Government intervention directed at a subset of firms in an industry, for example, can spur the developinent of additional safety precautions, innovation, or inforınation without coinpletely forgoing the checks and balances of private competition.

Our arguinent is not that partial-industry regulation is costless or that it should be pursued on an econoiny-wide basis. For one thing, partial-industry regulation raises constitutional issues of equal protection that are analyzed below. ${ }^{11}$ Additionally, as we inake clear, there are significant costs to partial-industry regulation that will clearly preclude its use in several regulatory contexts. But to be viable, partial-industry regulation must only succeed in domg better than the all-or-nothing alternatives. In some circumstances, we prefer the rifle to either the shotgun or no gun at all.

We begin by setting out both a theoretical and practical typology of partial-industry regulation. By analyzimg both the costs and benefits of such intervention, we show that government could use a diverse range of possible partial-industry interventions to promote competition. We next discuss the inonopsony standard as a guide for government intervention strategy. Potential equal protection problems resulting from disparate treatment of firms within the saine industry are then analyzed. We end

10. However, we later explicitly discuss situations in which partial-industry regulation might not be appropriate. See infra note 57 and accompauying text. In particular, when market failure injures people who are not in privity with the industry, such as with pollution, then competition between regulated and unregulated firms will not engender general industry compliance.

11. See infra notes $71-82$ and accompanying text. 
by discussing a series of applications-industry studies of oil, passenger airline service, news media, and long-distance telephone service-in whicl single-firm or partial-industry regulation is currently in place or might be justified.

\section{I \\ THEORY}

\section{A. A Typology of Partial-Industry Regulation}

Altliougl1 partial-industry intervention can take numerous forms, one can analytically distinguish among interventions that are directed at three different types of firms: dominant firms, frimge firms, and oligopoly firms. For purposes of our analysis it is useful to divide the regulations according to the type of firms at which they are targeted because the goals and forms of partial-industry interventions will vary depending on the types of firms addressed.

Many industries are cliaracterized by a pronounced dicliotoiny between dominant and fringe firms. "Dominant firms" are larger and seen to take the lead in setting price and otlier coinpetitive variables, while the sinaller "fringe firms" are followers, more passively inatching the competitive decisions of the dominant firms. The most inportant decision of the coinpetitive fringe often is, given the prevailing inarket price, to decide how much to produce. ${ }^{12}$ Other inarkets are more easily cliaracterized as "ohgopolies" in which a sinall number of firms of relatively equal size coinpete on such variables as price and quantity in a mucl more interdependent and strategic fashion. Oligopolistic industries have no clear followers or leaders; ratler, it is through the iterated history of firm interaction tliat a inarket equilibrium is fashioned. ${ }^{13}$

\section{Dominant-Firm Intervention}

Regulatory policies directed only at the dominant firm in an industry will often be similar to traditional forms of industry-wide regulation. Dominant-firm intervention will generally atteinpt to constrain the largest firm (or firms) in the industry from exercising inarket power to the detriment of consuiners. In its simplest form, doininant-firin intervention could pursue this goal by establishing the price at which the doininant firm must sell its product.

12. See F.M. Scherer, Industrial Market Structure and Economic Performance 232 (1970).

13. These market classifications do not, of course, reflect the prevailing organization of all markets. Some markets that consist of numerous small competitors comport more with our notions of perfect competition. 


\section{a. Potential Advantages Over Laissez-Faire Governance}

Dominant-firm regulation vis-à-vis no regulation can benefit consumers in two ways. First, like imdustry-wide intervention, setting a maximum price for a dominant firm can restrict the degree of market power it would wield in an otherwise unregulated market. An unregulated dominant firm would have imcentives to raise its price above its cost. This is especially true where fringe firms have only limited production capacities, and therefore consumers are forced to look to the dominant firm to fulfill demand. ${ }^{14}$ On the other hand, when dominant-firm prices are regulated, fringe firms will have difficulty maintaming sales if they raise their prices above the restrained price of a dommant firm. By setting the dominant firm's maximum price, a regulatory agency can effectively set an entire mdustry's maximum price. Thus, regulating a dominant firm can benefit consumers directly by lowering the dominant firm's price and indirectly by lowering the prices of its competitors.

Second, regulations that set a short-tern minimum price for dominant firuns might facilitate the entry of additional competition into the market and ultimately benefit consumers. Even though a bimding mimimum-price restriction in the short run might prevent consumers from enjoying the benefit of lower prices on the dominant firm's goods, this price restraint can actually facilitate competitive entry that nltimately inures to consumers' benefit. New firms might be deterred from entering the industry by the fear that entrenched firms will respond by reducing prices to make any entry unprofitable. By prohibiting these mitial price decreases, limited-time minimum-price standards may induce entry, ultimately increasing competition after the price fioors are removed.

One extreme form of post-entry attack that a dominant firm can use against entrants is predatory pricing. The established firm in such a scheme sets its prices below its production costs in order to drive out fringe competition and then raises its prices to monopoly levels. ${ }^{15}$ How-

14. Fringe firms in such situations tend to follow a dominant firm's price increase. For example, David Haddock presented a basing-point pricing scheme that illustrated such dominant/ fringe-firm interaction. Under this pricing strategy, the price that all customers paid for a good included a transportation price "as if" the good were shipped from a certain basing point. For example, under the "Pittsburgh-plus" steel system, the price of steel for Chicago purchasers would be calculated as if the steel had been shipped from faraway Pittsburgh even when it was sent froin nearby Gary, Indiana. Haddock demonstrated that because Pittsburgh manufacturers were dominant suppliers, steel firms in Gary had natural incentives to match delivered prices from Pittsbnrgh. David D. Haddock, Basing-Point Pricing: Competitive vs. Collusive Theories, 72 AM. ECON. REV. 289, 290-91 (1982).

15. There is currently a lively debate about whether such predation could ever be a profitable strategy for dominant firms. See, e.g., Matsushita Elec. Indus. Co. v. Zenith Radio Corp., 475 U.S. 574, 588-91 (1986) (discussing uncertain success of predatory-pricing conspiracies); Frank H. Easterbrook, The Limits of Antitrust, 63 TEx. L. REv. 1, 26-27 (1984) (illustrating difficulty of recouping profits lost under predatory pricing); Eric Rasmusen, Naked Exclnsion (1990) (unpublished manuscript, on file with authors). 
ever, firms need not follow such extreme pricing strategies because even nonpredatory price cuts can deter beneficial entry. Consider, for example, an industry in which a dominant firm without competition sets its price above its marginal cost. Because of a "learning curve" effect, new entrants might initially have higher costs but would eventually incur the same production costs as the dominant firm. Thus, a dominant firm may be able to deter entry by threatening to drop its price just slightly below a new entrant's cost. Because the dominant firm would have an mitial cost advantage, this price reduction need not be predatory in the sense that the product's price would still be above production cost. But the price reduction would mean that a new entrant would not be able to recoup any of its start-up costs, and would therefore be deterred from entering the market.

By restraining the ability of dominant firms to respond inımediately to entry with price cuts, minimum-price regulation could ensure nascent entrants limited protection from aggressive pricing by the incumbent firm. ${ }^{16}$ If minimum-price regulations were then relaxed, the new entrants could compete on an equal footing and consumers could benefit from coinpetition-induced lower prices. ${ }^{17}$ Thus, dominant-firm regulation inay be superior to laissez-faire pohicies because it can promote competitive price levels in two ways: it can restrain supracompetitive pricing by all the firms in an industry, and it can facilitate entry by temporarily limitimg dominant-firm price cuts aimed at deterring such entry.

\section{b. Potential Advantages Over Industry-Wide Regulation}

Dominant-firm regulation may also be superior to industry-wide regulation because it preserves the imdependence of fringe firms as a competitive check on the decisions of regulatory agencies. Although fringe firms will rarely have imcentives to price above a dominant firm, ${ }^{18}$ they may have strong imcentives to undercut dominant-firm prices to gain market share. By maintaining this potential for fringe-firm price cutting, dominant-firm mtervention may engender more competition than industry-wide imtervention.

Industry-wide regulation allows the coercive power of the state to

16. As discussed infra text accompanying note 80 , however, this restriction on a firm's ability to lower prices can be exploited by firms that control or capture the government's use of price regulation, thereby placing their rivals at a competitive disadvantage by forcing them to charge more than the market will bear.

17. This rationale for minimum-price regulation is similar to the use of import tarifs by developing countries to temporarily protect fledgling domestic industries from international competition that might have an exclusionary effect. Although neither import tariffs nor temporary minimum-price regulations are policies with general appeal, it is theoretically possible for them to be strategically responsive to specific structural contexts.

18. See supra note 14 and accompanying text. 
enforce anticompetitive collusion. As noted above, ${ }^{19}$ regulators can be "captured" by the firms they are supposed to restrain. Firms wishing to collude successfully must meet four distinct requirements:

(1) reaching an agreement,

(2) detecting breaches of the agreement,

(3) punishing breaches of the agreement, and

(4) deterring entry. ${ }^{20}$

A captured regulatory agency can drainatically facilitate collusion by helping firms overcoine each of these obstacles to collusion. Regulators can openly promulgate regulations stating the agreed upon price, and regulations can mandate that firms disclose the prices at which they sell. Perhaps most importantly, mdustry-wide regulations can punish price chiselers that undercut the supracoinpetitive price. Finally, many regulatory agencies have the discretion to limit new entry in certain industries. For example, public regulations limit the number of taxi hicenses used and control the difficulty of passing the bar examination to practice law. ${ }^{21}$

By leaving fringe firms coinpletely unregulated, dominant-firm regulation undermines the ability of "captured" regulators to organize a cartel. To be sure, an agency can still facilitate collusive agreement anong the firms of the industry by holding meetings and announcing a collusive price. But partial-industry intervention gives the unregulated firms greater opportunities to undermine the three other prerequisites for profitable cartelization. First, fringe firms cannot be forced to publicly disclose their prices, so it will be more difficult for the cartel to detect breaches by these firms of the collusive agreement. Second, fringe firms will not be bound by the dominant firm's regulated price, so price cutting will not be subject to legal sanctions. Third, new entry by nondominant firns cannot be legally proscribed. In fact, entry may even be encouraged if minimum-price regulations are maintained and dominant firms inust wait before lowering their regulated price. ${ }^{22}$ Our argument is not that dominant-firm regulation entirely eliminates the potential abuses of regulatory capture. We argue only that it initigates them.

To restrict dominant-firm prices, the designated public agency would need to undertake the same factual inquiry as is currently con-

19. See supra note 2 and accompanying text.

20. See Ian Ayres, How Cartels Punish: A Structural Theory of Self-Enforcing Collusion, 87 CoLum. L. REv. 295, 296 (1987) (outlining elements necessary to a successful cartel); D.K. Osborne, Cartel Problems, 66 AM. EcoN. Rev. 835, 843 (1976) (same).

21. See Peltzman, supra note 2, at 239 (noting "politically appropriate" price structure creates incentives for regulators to limit entry); Richard A. Posner, Theories of Economic Regulation, 5 BELL J. ECON. \& MGMT. SCI. 335, 344-48 (1974) (comparing the similar effect between regulatory devices and cartelization to demonstrate the value of regulation to industry).

22. See supra notes 15-16 and accompanying text (discussing minimum-price restrictions on dominant firms to encourage new entry). 
ducted in many mdustry-wide regulatory regimes. Namely, it would have to determine what price would provide the regulated firm with a "fair return" on capital. Initially, therefore, dominant-firm intervention in the form of settimg prices would not reduce the informational burden of regulatory agencies as they would still need to estimate costs and determine a reasonable price. The freedom of unregulated firms to undercut the dominant firm's regulated price, however, could provide guidance for the uncaptured but uninformed regulator. The persistence of price cutting by fringe firns provides strong evidence for uninformed regulators that the dominant firm's price has been set too high. Indeed, price cutting by fringe firms imight even lead the dommant firm to lobby the agency for lower regulated prices. ${ }^{23}$

Our theory of dominant-firm regulation gams its strength from the critiques of both the laissez-faire and industry-wide policy perspectives. Dominant-firm regulation acknowledges the dangers of both private and public supracompetitive pricing and proposes an alternative in which the regulated and unregulated portions of an industry serve to check each other's conduct. Under dominant-firm intervention, the portion of the market that fails least will, im a sense, determme the level of competition. If either the regulators or the unregulated firms want to set a competitive price, then the other portion will necessarily respond and conpetition will prevail. ${ }^{24}$ The law of one price ${ }^{25}$ will tend to drive the market price toward the price generated by the more competitive portion of the industry. In a world where either portion can fail to produce a competitive price, it might be best to maintain both a regulated and an unregulated market presence, allowing consumers the benefit of the most competitive price that either can produce. ${ }^{26}$

23. See infra notes $115-16$ and accompanying text (noting AT\&T's petition to lower its restricted rates in response to MCl's competitive influence).

24. This result will depend on the ability of the inore competitive portion to supply the industry demand at the more competitive price, and will be limited if there are capacity constraints. Also, as noted above, minimum-price regulations on dominant firms could constrain their ability to match a lower fringe price.

25. Competitive markets generally approach an equilibrium with one price because individual sellers cannot sell at a price above their competitors' prices and would not want to sell at a lower price. For a definition and criticism of the law, see Joseph E. Stiglitz, The Causes and Consequences of the Dependence of Quality on Price, 25 J. ECON. LITERATURE 1, 7-10 (1987).

26. In algebraic terms, if the regulators set a price $P_{r}$ and the unregulated fringe producers set a price of $P_{f}$, then the preference of consumers to buy the cheapest product will tend to produce a market price $P_{m}$ equal to $P_{m}=\min \left(P_{r} P_{f}\right)$. The failure of regulated and unregulated firms is represented by the deviations of their prices above the competitive level, $P_{c}$. Heuristically, the potential for public and private market failure could be modeled by having $P_{r}$ and $P_{f}$ as randomly distributed variables. In such a crude model the superiority of dominant-firm regulation is captured in the notion that the expected price under the mixed (partial-industry regulation) regime would be lower than the expeeted price under either industry-wide or laissez-faire regimes. 


\section{Fringe-Firm Intervention}

An alternative partial-industry regulatory strategy focuses government attention on fringe producers. To implement a fringe-firm strategy, regulators would leave the dominant firm in the industry unregulated and would intervene to affect the behavior of fringe firms. While dominant-firm intervention seeks to restrain the behavior of dominant firms, fringe-firm intervention seeks to create or maintain the existence of additional competitors. Instead of directly regulating the behavior of firms im an industry, as with the price regulation of dominant-firm intervention, ${ }^{27}$ fringe-firm intervention seeks to change the structure of the industry and thereby induce more competitive behavior. ${ }^{28}$

A broad range of regulatory strategies could promote the existence of additional competitors. The government could make available a wide variety of subsidies to small competitors. It could directly subsidize new entrants to preserve these fringe firms with loans at favorable rates. ${ }^{29}$ The government in its capacity as a consumer could also promote the competitive presence of fringe firms by patronizing them. For example, many American state governments attempt to promote the econo1mic viability of smaller banks by placing state government deposits with them. ${ }^{30}$ Finally, im the extreme case the government itself could enter a market as a producer of the good in question. The diversity of these partial-industry regulations is illustrated in greater detail in the case studies discussed below. ${ }^{31}$

Efforts to imcrease the number of competitors im a market by such fringe-firm imterventions might structurally serve to miprove the compet-

27. See supra notes $14-26$.

28. Fringe-firm interventions might fit into a larger system of "structural" interventions. Structural theories of collusion identify inany structural variables, such as capacity constraints and product differentiation, that might affect the ability of industries to fulfill the prerequisites of successful cartelization. See generally Ayres, supra note 20, at 295-325. Further research might be directed at explaining ways that governinent could intervene to alter the structural aspects of firms and inprove the competitive performance of an industry.

29. See infra notes 96-103 and accoinpanying text (proposing that government might have intervened to preserve People Express as a competitive presence in the airline industry).

30. Similarly, purchases by the Uinited States government at one point accounted for one-half of American Motors' sales. It might be possible to justify the minority and small-business set-aside programs on a similar ground. See Drew S. Days, III, Fullilove, 96 YALE L.J. 453, 477 (1987) (suggesting that set-aside programs enable the beneficiaries to compete effectively). Many of these ineasures are adopted, however, inore in response to government interests in redressing past discrimination than in restraining supracompetitive pricing.

Alternatively, fringe entry could be encouraged by a tax scheme that disproportionately taxed incumbent firms. This program would be similar to tariff policies tailored toward spurring domestic production. A progressive corporate-tax system might have a similar effect by giving smaller, newer firms a coinpetitive advantage. Although the global nature of such taxes inakes them poor instruments for targeted coinpetitive strategies, the idea might not be lacking inerit for applications linited to specific industries.

31. See infra notes $83-116$ and accompanying text. 
itive performance of an industry. Both theory and practice strongly support the proposition that in inany contexts increasing the number of competitors will engender more competitive behavior..$^{32}$ For example, in his seminal article $A$ Theory of Oligopoly, George Stigler presented a model showing that larger cartels would have more difficulty detecting breaches of their agreements. ${ }^{33}$ This same outcome is replicated in simple inodels of tacit collusion, such as the noncooperative Cournot inodel. ${ }^{34}$ The robust result in these models is that as the number of firms increases, the inarket price falls toward the competitive level..$^{35}$

Several studies have empirically validated this intuition. Paul MacAvoy's detailed study of railroad cartels dramatized how the existence of even a third major competitor significantly destabilizes efforts at cartelization. ${ }^{36}$ Studies of the airline industry confirm this result. ${ }^{37}$ Cross-sectional studies that inust crudely aggregate data from disparate industries have generated inore varied results, but as Frederick Scherer has suminarized, "there is a rather robust tendency for a positive association to ennerge between seller concentration and profitability." ${ }^{38}$ Again, the preponderance of evidence supports the conclusion that fewer sellers have a greater ability to raise prices above costs.

Moreover, empirical evidence indicates that government ownership of businesses does not necessitate inefficient production. For example, in Canada the publicly owned railroad has achieved the same efficiency as its private rival. ${ }^{39}$ The possibility that fringe-firm interventions can promote competition is also directly confirmed by private interventions in

32. An important prerequisite for this position is the existence of some barriers to entry. In perfectly contestable markets even a small number of producers might be forced to behave competitively by the ever-present threat of potential competition.

33. See George J. Stigler, $A$ Theory of Oligopoly, 72 J. PoL. EcoN. 44, 50-51 (1971) (presenting calculations proving the chance of detecting price cutters decreases as the number of rivals increases).

34. In the Cournot model, which is standard in the industrial organization literature, identical firms choose how much to produce given a fixed expectation of their competitors' production. See JeAN TiRole, The Theory of INDUSTRIal ORganization 218-21 (1988). As the number of competitors increases, the equilibrium price drops toward the competitive price. Id. at 221-23.

35. See ERIC RASMusen, Games AND INFORMATION: AN INTRODuction to Game THEORY 262 (1989).

36. Paul W. Macavoy, The Economic Effects of Regulation: The Trunk-Line Railroad Cartels aNd THE INTERstate Commerce Commission Before 1900, at 25-78 (1965) (detailing how the entrance of third railroad brought about collapse of agreement between two incumbent railroads).

37. See Ian Ayres, Determinants of Airline Carrier Conduct, 8 INT'L REv. L. \& EcoN. 187 (1988) (rejecting the hypothesis that airlines are contestable markets and noting effect of structural variables on airline collusion).

38. See SCHERER, supra note 12, at 278-79.

39. See Douglas W. Caves \& Laurits R. Christensen, The Relative Efficiency of Public and Private Firms in a Competitive Environment: The Case of Canadian Railroads, $88 \mathrm{~J}$. PoL. EcoN. 958, 973-74 (1980); see also John Vickers \& George Yarrow, Economic Perspectives on Privatization, J. ECON. PersP., Spring 1991, at 111 (discussing effects of privatization). 
contiguous markets. In a number of contexts the downstream purchasers of products willingly subsidize the entry and contmued existence of additional upstream competitors. This practice of "second-sourcing" is commonly used, for example, by governments in procuring defense contracts and by automobile manufacturers seeking the production of specialized imputs. ${ }^{40}$

As the name suggests, the goal of firms engaged in second-sourcing is to promote the presence of additional sources of supply. The theory behind second-sourcing strategies is relatively simple: downstreain firms willingly incur the costs of subsidizing additional upstream competitors because the presence of such competitors will undermine the market power of the mcumbent producers and ultimately lower the downstream input prices. The effectiveness of second-sourcing in reducing upstream market power can be gleaned from the resistance of upstreain incumbents to this strategy. For example, in Barry Wright Corp. v. ITT Grinnel Corp. ${ }^{41}$ a downstream purchaser of inechamical snubbers, a kind of shock absorber for pipes in nuclear power plants, contracted to subsidize the entry of a new upstream producer. The incuinbent snubber producer reacted immediately by cutting its downstream price and attempting to enter into a long-terin, effectively exclusive arrangeinent with the purchaser. ${ }^{42}$ Upstream incumbent producers resist secondsourcing for the same reason that downstream consumers undertake the strategy: additional competition will limit the ability of upstream producers to extract inonopoly rents from downstreain consumers.

A striking prerequisite for private second-sourcing strategies, however, is a concentrated downstream demand for a given product. Because second-sourcing generally entails subsidization, it is difficult to induce all downstream firms to contribute to the second-sourcing efforts of their coinpetitors. Regardless of whether or not they contribute to the subsidy, all downstreain firns benefit from the coinpetitive presence of additional upstreain firms. Thus, downstream rivals would prefer to free ride on the investments of their rivals in estabhshing these upstreain competitors. In other words, second-sourcing is a public good to downstream competitors, and the more diffuse the downstream competitors the less they will invest in the public good of upstream entry. Only concentrated downstream industries are likely to overcome the underinvest-

40. See Joseph Farrell \& Nancy T. Gallini, Second-Sourcing as a Commitment: Monopoly Incentives to Attract Competition, 103 Q.J. EcoN. 673 (1988) (discussing second-sourcing as a means to a long-term source of supply); Michael H. Riordan \& David E.M. Sappington, Second Sourcing, 20 RAND J. ECON. 41, 41 (1989) (stating that the Department of Defense fosters competition among suppliers by sustaining second sources).

41. 724 F.2d 227 (1st Cir. 1983).

42. Id. at 229. Judge Stephen Breyer, however, rejected the arguments of the failed entrant that this behavior constituted either actionable predation or acts of monopolization. Id. at 240 . 
ment problein. It is not surprising, therefore, that leading examples of second-sourcing occur when the downstream firm is a monopsonist of speciahized products, as is the case $m$ the defense and automobile input markets.

The fact that second-sourcing strategies are not undertaken in industries with more diffuse downstream demand does not indicate, however, that such strategies could not efficiently improve competitive performance. The willingness of concentrated buyers to imcur the cost of subsidization in the expectation of lower input prices is compelling prima facie evidence of its efficiency. ${ }^{43}$ Because of the free-rider problem, however, industries with diffuse downstream competitors are unable to undertake the collective action necessary to optimally invest in second sources. With diffuse demand, the transaction costs of reaching such subsidization agreements are prohibitive. Yet the fact that second-sourcing is cost justified when demand is concentrated is strong evidence that it will also be cost justified when demand is diffuse. The possibility of efficient second-sourcing in markets with diffuse demand is a forceful argnment in favor of fringe-firm imtervention, which is simply a public form of the second-sourcing strategy. Regulators, acting as the agents of diffuse downstream consumers, can avoid the collective action problem of free riding and subsidize additional entry. ${ }^{44}$

Fringe-firm interventions as public attempts to encourage competition through second-sourcing have two informational advantages over industry-wide interventions. First, efforts to promote the continued existence of frimge firms would not put the saine informational demands on regulators as would, for example, imposing industry-wide prices. "Existence" subsidies, which merely provide assistance to new entrants, would require less detailed information about production costs and reasonable returns. ${ }^{45}$ Second, the subsidized frimge firms would provide regulators with information to more effectively assess and regulate the

43. One should not confuse efficiency with price. It is possible that second-sourcing might inefficiently reduce the upstream price. An upstream monopolist with low cost and high monopoly markup might be more efficient than a competitive duopoly with lower prices but higher unit costs. This is an example of the Williamson tradeoff. See OLIVER WILliamson, ANTITRUST Economics: Mergers, Contracting, and Strategic Behavior 22-23 (1987). Consumers, however, will prefer lower prices even if there are inefficiently higher costs of production.

44. The concepts of second-sourcing and fringe-firm intervention can be applied to downstream production as well. Private manufacturers often are willing to subsidize downstream retailers to promote downstream intrabrand competition and reduce the monopsony power of individual retail buyers. Similarly, one could imagine fringe-firm government intervention creating additional downstream copyright distributors, such as in Broadcast Music, Inc. v. Columbia Broadcasting Sys., Inc., 441 U.S. 1 (1979) (only two distributors offered "blanket license" packaging of artists' performance rights), which could be worthwhile to protect the interests of diffuse upstream sellers.

45. This point would not always be true. To determine the smallest subsidy that would support new entry, regulators would need to estimate the costs and revenues for the individual firms. 
performance of other firms in the industry. This is especially true when governinent engages in the extreine strategy of government ownership because the process of producing the good itself provides regulators with more reliable firsthand cost data about other firms. Data generated from such frimge-firm intervention can then be used to set the dominant firm's price more precisely. Thus, fringe-firm interventions might be superior to industry-wide intervention in an information gathering context both by demanding less information from regulators and by supplymg regulators with more useful data.

In sum, the pervasive use of private second-sourcing strategies by concentrated buyers argues in favor of public fringe-firm strategies that also encourage the benefits of increased upstream competition. Government is especially well placed to provide the public good of increased competition by mducing and maintaining the structural conditions for such competition.

\section{Oligopoly Tournaments}

The dichotomy between dominant and fringe firms breaks down in a number of mdustries that have a small number of firms of relatively similar size. There is, however, a third class of regulatory interventions that could be particularly appropriate for these "oligopolies." In such instances the very similarity of the firms makes "tournainent" regulation an effective policy tool. In a regulatory tournainent an agency's treatment of individual firms depends on their relative perfornance.

The use of grading curves in teaching is a classic example of a tournament. The grades given to the individual players, or students, can be viewed as "payoffs" that depend on the perforinance of others in the class. ${ }^{46}$ Many current regulations also establish tournaments among firms in an industry. Affirmative action guidelines create such a tournament because they set hiring targets for federal contractors based on the average minority employment in the market. These guidelines create an interdependence among the contractors because an evaluation of each contractor's hiring practices depends on the hiring practices of others in the market. ${ }^{47}$ Alternatively, the due-care standards applied to physician perfornance in medical malpractice suits often depend upon the prevailing customs of other doctors in a relevant geographic market. ${ }^{48}$ The "diaguostically related group" method of reimbursing health care practi-

46. See RASMUSEN, supra note 35 , at $167-68$ (toumament games use a benchmark based on competitors' performance).

47. See James J. Heckman \& Kenneth I. Wolpin, Does the Contract Compliance Program Work? An Analysis of Chicago Data, 29 INDUS. \& LAB. REL. REV. 544, 546-48 (1976) (noting steadily growing percentage of minority workers among the work force of those firms seeking governinent contracts).

48. See Marshall S. Shapo, Tort AND INJURY LAw $\$ 4.04$, at 227-38 (1990). 
tioners in the Medicare context also exemplifies tournament competition. This method ties Medicare payments for treating a patient to the average costs to other physicians in treating patients having similar illnesses. ${ }^{49}$ In addition, game theorists have paid particular attention to "patent race" tournaments in which the first firm to innovate gains the enhanced profits of patent protection..$^{50}$

Tournament regulation is distimguishable from dominant-firm or fringe-firm regulation by the timing of government intervention. The essence of both dominant-firm and fringe-firm regulation is ex ante disparate treatment: some firms in an industry are regulated while others are not. In contrast, tournament regulation involves disparate treatment that only attaches ex post, at the end of play. Froin an ex ante perspective, firms competing in a regulatory tournament are treated the saine: they have an equal opportunity to "wm" a tournament. For example, any firm is free to invest resources in research and development; the disparate treatunent of patent protection attaches only after the patent race has been won. From this ex ante perspective then, tournament interventions are a form of industry-wide regulation that makes the payoffs to the individual firms interdependent. Tournainent regulation strives to induce enhanced competition throughout an entire industry for a tournament's prize, thereby increasing the efficiency of the industry.

A particularly effective class of tournainents analyzed in the gametheory hiterature involves a form of "yardstick competition." 51 Regulators of public utilities can engender such yardstick competition by basing each utility's price upon the average costs of other similar utilities. Such a regulation can give individual utilities strong incentives to reduce the cost of their own production because their regulated price is independent of their own cost-saving efforts. ${ }^{52}$ Yardstick competition accordingly creates a tournament in which a firm's profits are determined by its ability to generate lower costs than its competitors. This form of govern-

49. See Andrei Shleifer, $A$ Theory of Yardstick Competition, 16 RAND J. EcoN. 319, 325-26 (1985) (discussing diagnostically related group reimbursement scheme for health-care professionals).

50. See Yoram Barzel, Optimal Timing of Innovations, 50 REv. ECON. \& STAT. 348, 353 (1968) (social costs of inducing innovation can outweigh any social benefit derived); see also Richard J. Gilbert \& David M.G. Newbery, Preemptive Patenting and the Persistence of Monopoly, 72 AM. ECON. REv. 514 (1982) (examining likeliliood of do1ninant firms monopolizing patents to exclude potential competitors); Jennifer F. Reinganuin, Innovation and Industry Evolution, 100 Q.J. EcoN. 81 (1985) (stating that the behef in the existence of many future possible innovations depresses the competition among firms to actually innovate).

51. See generally Shleifer, supra note 49, at 319-25 (providing overview of yardstick competition generally and witl structural variations); Joseph Farrell, Monopoly Slack and Competitive Rigor: A Simple Model (Massachusetts Institute of Technology, 1985) (unpublished manuscript, on file with autlıors).

52. This independence is true only to the point when the individual utility's costs are again considered, together with the costs of all other utilities, in establishing a new regulated price. At that time the utility's price would be indirectly affected by its cost-saving efforts. 
ment regulation puts the utilities in a type of prisoner's dilemma; although they collectively prefer not to undertake the effort of reducing cost, individually they are driven to keep ahead of their competitors. In equilibrium, yardstick coinpetition can induce efficient behavior in which the utilities, striving to gain a coinpetitive advantage, are all driven to the coinpetitive optimum.

In such ohgopolies it inay also be beneficial for the regulator to employ either dominant- or fringe-type interventionist strategies. For exainple, Michael Spence has shown that when firms incur fixed costs of producing different types of products, competitors will be led to produce the type or quality that is valued niost by the marginal consumer-in an effort to induce these almost indifferent consumers to buy-and ignore the average consumer. ${ }^{53}$ Social welfare is sacrificed when such firm behavior demies the majority of consumers their preferred product type. Partial-industry regulation could at least theoretically overcoine this market failure by redefining the margin of custoners over which unregulated firms inust coinpete. ${ }^{54}$ If partial-industry regulation constrained a subset of firms to produce the quality or type of product preferred by the average consumer, the competition froin these firms could force the unregulated firms to produce the inore widely valued good as well. ${ }^{55}$ Alternatively, partial-imdustry regulation could force an entire industry to treat employees better if unregulated firms are to attract einployees froin a dominant firm whose working conditions are regulated.

Like fringe-firm intervention, yardstick coinpetition has distinct informational advantages for regulators. The crucial aspect of utility regulation is finding the appropriate cost benchmark that will induce efficient behavior and assure a sufficient return. Yardstick conpetition, which bases price on an average of the cost of similar utilities, is especially attractive because utilities in otherwise distinct geographic inarkets compete in a sense to lower their own costs and increase their profit. Thus, the average utility-cost figure provides regulators with a cost benchmark that closely approximates true cost.

Therefore, all the preceding forms of .partial-industry regulation have the potential to foster advantageous competition. Conpetition will force the unregulated firms to inatch the regulated contractual offers of the regulated firms, resulting in a variety of benefits for einployees and consumers. A partial-industry regulation regime retains an unregulated market presence that can initigate corrupt or imisguided government regulation. By delegatimg part of the regulatory role to the conipetitive pro-

53. A. Michael Spence, Monopoly, Quality, and Regulation, 6 BELI J. EcoN. 417,417 (1975).

54. See id. at $428-29$.

55. In practice, however, regulators will face informational hurdles in determining the desires of the average consumer. See id. 
cess, partial-industry regulatory regimes seek to restrain the private exploitation of monopoly power without substituting the potential for public exploitation through capture. ${ }^{56}$

In partial-industry regimes of regulation, competition between the regulated and unregulated portions of the industry will not, however, always engender beneficial comphance. Partial-industry regulatory strategies are only likely to be appropriate when the market failure at issue mjures someone in contractual privity with the firms in the industry. For example, partial-industry regulation will not be effective in inducing imdustry-wide coinphance with pollution standards. Because the people who are injured by industrial pollution are often not, or at least not exclusively, im privity with the offending corporations, competition will not force the unregulated firms to match the behavior of the regulated firms. Forcing a subset of oil compamies not to spill oil will not coinpel unregulated firms to take more care. Indeed, the regulated firms that bear additional costs of regulatory comphance will put less competitive pressure on their unregulated rivals. Yet when it is properly restricted to market failnres involving contractual privity, ${ }^{57}$ partial-industry regulation provides an innovative possibility for improving market performance.

In sum, partial-industry regulation can seek to proinote competition in three ways: by restraining anticompetitive behavior of doininant firms; by promoting additional entry of fringe firms; or by engendering tournament competition throughout the industry for an interdependent prize. Both public and private market governance can fail to provide efficient resource allocation. Partial-industry regulation creates dual governance of individual markets by utilizing both public and private forces. The coinpetition between these public and private systems of economic governance can serve as a check on both forms of market failure. We are not suggesting that a government presence is appropriate in most or even many imdustries. Instead, rational regulation should assess when the types of partial-industry regulation discussed above will produce better results than the more traditional regulatory alternatives.

56. Elsewhere we have suggested that "tripartism"-the empowerment of third-party consumer groups with regulatory enforcement discretion-could be used to promote cooperative regulation without falling prey to the costs of capture. See AYRES \& BRAITHWaITE, supra note 6. For a discussion of third-party participation in the regulatory process, see the Conclusion of this Article.

57. This privity requirement for partial-industry regulation also supports our analysis of a monopsony standard for consumer protection. See infra notes 58-70 and accompanying text. Monopsonists, as consumers in privity with their suppliers, often undertake strategies that mimic or are analogous to a variety of partial-industry interventions discussed herein. 


\section{B. A Monopsony Standard for Government Intervention}

These theories of partial-industry intervention gain support from an analysis of monopsomist behavior. The conduct of single buyers (monopsomists) or concentrated buyers (oligopsonists) provides a unique vantage point for consumer-protection advocates. Because downstream monopsonists have nrarket power, ${ }^{58}$ they are often able to utilize this power to effectively protect themselves fron paying upstream prices above the conpetitive level. ${ }^{59}$ In a wide variety of contexts, monopsonists will improve nrarket efficiency by inducing inore competitive conditions of supply. Put simply, governments interested in proinoting consumer welfare should often emulate what a monopsonist consuiner would do.

This monopsony standard for government intervention can support Inany of the partial-industry regulations discussed above. Most directly, a monopsony analysis underscores the potential usefuhress of fringe-firm intervention. One way to reformulate a regulator's decision about whether to use a particular form of fringe-firm intervention is to ask

58. The determination of market power is linked to the underlying definition and boundaries of a relevant nuarket. For example, under the Departnıent of Justice Merger Guidelines relevant antitrust markets are defined so that the market includes all colluding sellers who would have the ability to raise prices by 5\%. ANTITRUST DIV., U.S. DEP'T OF JUSTICE, U.S. DEPARTMENT OF JUSTICE MERGER GUIDELINES 4 (1982) ("[T]he Departnient will hypothesize a price increase of five percent and ask how miany buyers would be likely to shift to . . . other products within one year.") Analogously, if the industry has an upward-sloping supply curve, a monopsonist buyer with inarket power should have the ability to lower the price. See infra note 59.

59. At times monopsonists have incentives to distort supply by inefficiently depressing their deinand to lower the cost of goods purchased. Figure 1, below, illustrates that monopsonists will only purchase up to the point at which the marginal cost of the good purchased, depicted as the marginal-outlay line, equals the nonopsonist's marginal value, depicted as the deinand curve. If the production of the good involves the use of scarce resources so that the supply curve is upward sloping, then the nionopsonist will restrict the amount it purchases below the competitive level, $q_{c}$, to the monopsonist's equilibrium demand of $q_{m}$. By suppressing the quantity demanded, the monopsonist is able to increase its profits by reducing the conpetitive price from $p_{c}$ to $p_{m}$.

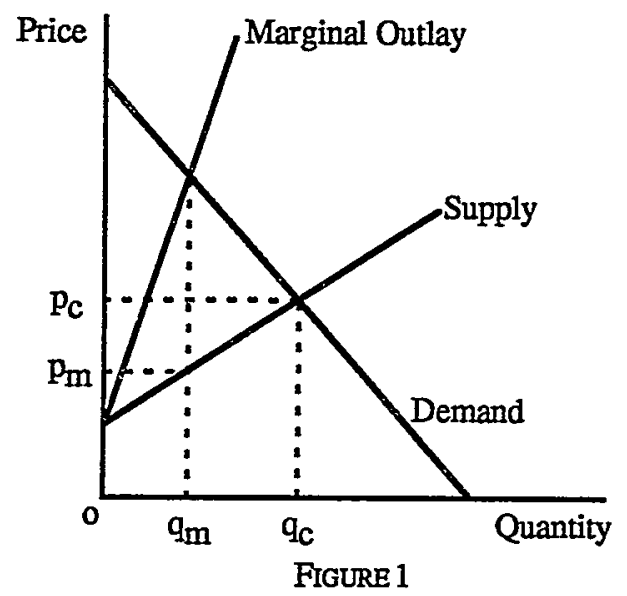


whether a downstream nıonopsonist would be willing to subsidize upstream entry. The decisions of a hypothetical monopsonist would replicate a consumer-welfare standard because such a downstreani consumer fully internalizes the costs and benefits of the second-sourcing strategy and would not subsidize an upstream firm unless the ultimate benefits it would reap outweigh the costs of the venture. ${ }^{60}$ In short, government sliould consider second-sourcing where a monopsonist would. ${ }^{61}$

The monopsony standard also supports the use of what Richard Romano has called "excessive consumption" by government. ${ }^{62}$ In industries witl large fixed costs and declining marginal costs it is possible that average costs will everywhere be above the consumer deniand curve. In this situation no producer can profitably supply any level of deinand and there might be no entry into the industry even though the forgone consumer surplus on inframarginal purchases would inake production socially efficient. Romano has shown that consuiners might therefore engage $\mathrm{m}$ excess consumption-consunption beyond their nonstrategic, normal levels of deniand-to niake production profitable and induce entry. ${ }^{63}$ Thus, Romano is able to explain wliy residents of Lake Wobegon would be willing to buy their toasters at the local hardware store even though the purchase would be cheaper at the K-Mart in a bigger city. ${ }^{64}$

Just as second-sourcing proniotes the entry of second (or third) sources of supply, excessive consumption can be thought of as a form of "primary-sourcing" that seeks to encourage an mitial source of supply. But as with second-sourcing, excessive consumption of this type is unlikely to be a successful form of fringe-firm intervention if there is a diffuse group of consumers: each consunier would prefer to liave the others bear the cost of subsidizing the excessive consumption. As before, government employing the monopsony standard inight act on behalf of diffuse groups to maintain adequate consumption and ensure a source of supply.

The minimum-price regulation involved in donimant-firm intervention can have an analogous second-sourcing effect. As seen in the Barry

60. Downstream monopsonists might also engage in second-sourcing to ensure an uninterrupted supply of an essential input that would be threatened if a single supplier faced a strike or natural disaster. These additional reasons for private second-sourcing equally justify government intervention on behalf of diffuse consumers when assurance of an uminterrupted supply is desirable.

61. However, government might not wish to second-source in all situations that a monopsonist would because the government's cost of implenentation and administration of the regulatory scheine might outweigh the benefits.

62. See Richard E. Roinano, When Excessive Consumption is Rational, 81 AM. Econ. REv. 553,553 (1991).

63. See id. at 562 ("Individuals consume beyond their demands to keep the firm in business and to protect their surpluses.").

64. Id. at 553 (citing GARRISON KeILlOR, LAKE WOBEGON DAYS 95-96 (1985)). 
Wright case, ${ }^{65}$ incumbent producers are likely to cut prices in response to second-sourcing strategies designed to foster new entry. A monopsomist can retain the benefits of these price cuts and the competitive benefits of second-sourcing by continuing to buy a certain proportion of its demand from higher priced new entrants. When deinand for a product is diffusely distributed among several competitors, however, it can be difficult to organize these mdividual buyers to purchase a proportion of their demand froin higher priced entrants. Individual buyers, while wanting the increased competition, would rather buy from the lower priced incumbent. Thus, each buyer would leave it to its competitors to pay the second-sourcing subsidy, destroying any agreement among them. Minimum-price regulation of incumbent sellers facing new entry is an indirect way of re-creating the result of inonopsonistic or oligopsonistic buying groups: the fixed minimum price removes the ability of individual buyers to chisel on a second-sourcing strategy and allows new entrants with higher initial production costs to survive. ${ }^{66}$

Maximum-price regulation of dominant firms and ohgopoly tournainents can also be seen as public analogues of private monopsony behavior. The market power of a monopsonist will, like maximum-price regnlation, allow it to constram the ability of dominant firms to sell at supracompetitive prices. Monopsonists wishing to retain the procompetitive effects of fringe supphiers would rationally negotiate individualized prices related to the costs of the individual sellers. Thus, the maximum prices resulting from cost-conscious negotiations by monopsomists with dominant firms are likely to be lower than the prices negotiated with higher cost fringe supphiers. This is similar to a partial-industry intervention scheme employing both dominant-firm price settimg and fringe-firm subsidization. The monopsony standard harmonizes so well with partialindustry regulatory strategies because monopsomists often find it in their interest to negotiate individualized deals with their suppliers. Disparate treatment is then the essence of the monopsomist's attempts at consumer self-protection. ${ }^{67}$

65. See supra notes 41-42 and accompanying text.

66. Minimum-price regulation substitutes for direct second-sourcing strategies-but at a cost. Monopsonists that sccond-source can still buy from mcumbents at a lower price than the subsidized entrant. Mimimum-price regulation forces consumers, even the nonsubsidized incumbents, to buy from all producers at a higher price. Of course, under a monopsonist supported second-sourcing scheme the imcumbent dominant firms know that monopsomists might continue to purchase from new entrants at a higher price, and will therefore have reduced imcentives to cut their price. Thus, the amount of price cutting in response to entry will not be as great when there is monopsonist demand and consequently the relative cost of minimum-price regulation will not be as high.

67. The individualized negotiation of price is often referred to as "price discrimination." Although the practice of negotiating individual prices is often used to extract consumer surplus by sellers with market power, see Ayres, supra note 8, at 827-33 (discussing price discrimination techniques), price discrimination can also be used by consumers to extract producer surplus from the supply side of the market. 
Finally, the private use of exphicit and imphicit tournainents, which make suppliers' profits dependent on the conduct of their competitors, argues for greater consideration of public interventions of this form. Buyers with market power routmely use not only explicit bidding but in dynamic contexts they also make decisions about repeat business depending on the relative levels of service provided by supphers. In addition, firms buying services froin their employees often resort to contests that reward employees on their relative marketing success or performance.

A monopsony standard provides not only a powerful tool for analyzimg how government imght intervene to protect consumers but also a limiting primciple for determining when intervention is appropriate. For although the private practice of second-sourcing provides powerful evidence that there are situations where public second-sourcing or fringefirm intervention might benefit consumers, the fact that second-sourcing is not undertaken by all monopsomists suggests that there will be inany situations in which frimge-firm intervention is not appropriate. Therefore, the monopsony standard provides a sufficient condition for governmental nonintervention but only a necessary condition for intervention. By this we mean that if a monopsonist would not intervene to secondsource, then that shonld be sufficient to deter government from intervening on behalf of a more diffuse group of consumers. But the converse does not hold. The fact that a monopsomist would second-source does not imply that government should. The costs of administering public second-sourcing - mcluding the possibility of captured partial industry regulation-might militate against government intervention even in those situations when monopsomists would act. Thus, the monopsony standard at once holds out the possibility of beneficial partial regulation but at the saine time provides a one-tailed test to circumscribe its use.

The industrial-organization literature is a rich source of information that can sled light on the application of this hypothetical monopsony standard. In attempting to analyze how a hypothetical monopsonist would behave, consumer-protection advocates inight begin by assessing the degree to which additional competitors are likely to reduce an industry's prices. Monopsomists will tend to second-source when the ultimate gains from lower imput prices exceed the costs of the imitial second-sourcing subsidy. As is generally the case, the final analysis will turn on an empirical assessment of the costs and benefits of the regulation, including the costs of agency capture. ${ }^{68}$

68. The presence of several similarly sized firms in a partial-industry regulatory environment might serve to offset the ability of any individual firm to "capture" an agency. Partial-industry regulation would prompt firms to compete with each other, while current industry-wide regulatory approaches place firms on equal footing and encourage them to share a common and powerful regulatory agenda. 
Because the forms of partial-industry regulation are so diverse, the specific administrative details and difficulties of such intervention are largely beyond the scope of this Article, although some particulars are discussed below in the industry studies. ${ }^{69}$ Our goal here is to point to the possibility of a new genre of regulatory possibilities that is, unfortunately, largely being ignored by the public sector despite having long been a staple of private consuiner protection. The possibility of fringe-firm intervention or public second-sourcing on behalf of consumers is politically unacceptable to the current laissez-faire regnlatory mind-set. Critics should recognize, however, that authorizing government agencies to disparately subsidize fringe-firm production is less invasive than many traditional forms of industry-wide regulation, such as the airline-fare regnlation that prevailed for several decades prior to deregulation. ${ }^{70}$ The fact that consumers with market power often protect theinselves with private analogues to partial-industry intervention supports the argument that government should emulate these strategies to protect less powerful groups of consuiners.

\section{Equal Protection Impediments to Partial-Industry Regulation}

The potential benefits stemming from the various forms of partialindustry regulation will generate umque probleins of administration and enforcement. This Section highlights Equal Protection as an important equitable difficulty inherent in partial-industry regulation. ${ }^{71} \mathrm{~A}$ chief coinplaint among industry participants would concern the fundamental

69. See infra notes 83-117 and accompanying text.

70. For a discussion of fringe-firm subsidies for airline passenger service, see infra notes 100-01 and accompanying text.

71. In general economic regulation will not be struck down on equal protection grounds. In City of New Orleans v. Dukes, 427 U.S. 297, 303 (1976), the United States Supreme Court stated that it would take a deferential approach to any equal protection challenge to state economic regulation. The city of New Orleans had banned pushcart vendors from the French Quarter but allowed those that had been there for a long time to remain. An excluded vendor argued that the grandfather-clause provision violated his equal protection rights. The Court rejeeted his challenge, noting that unless the distinction drawn by a regulation "trammels fundamental personal rights or is drawn upon inherently suspect distinctions," it need only be "rationally related to a legitimate state interest." Id. The Court specifically overrulei Morey v. Doud, 354 U.S. 457 (1957), which was the "only case in the last half century to invalidate a wholly economic regulation solely on equal protection grounds." Dukes, 427 U.S. at 306.

The Dukes Court noted that the rational relationship between a regulatory scheme and its objective need not reflect "mathematical exactitude." Id. at 303. Specifically, regulations are permissible if implemented "step by step" and if they "only partially ameliorate a perceived evil." Id. Thus, regulatory tactics such as piecemeal escalation of government intervention affecting only dominant or fringe firns would be pernissible under Dukes. See also Dandridge v. Williams, 397 U.S. 471, 486-87 (1970) (stating that "the Equal Proteetion Clause does not require that a State must cloose between attacking every aspect of a problem or not attacking the problem at all"); Metropolis Theatre Co. v. City of Chicago, 228 U.S. 61, 69 (1913) (asserting that "[t]he problems of government are practical ones and may justify, if they do not require, rough accommodations"); Lindsley $v$. Natural Carbonic Gas Co., 220 U.S. 61, 78 (1911) (holding that a "classification having some 
fairness of treating firms differently. For example, under dominant-firm intervention those firms subject to price regulation would argue that it is unfair for their competitors to go unregulated. Under fringe-firm intervention, those firms without government subsidies would argue that it is unfair that they are not also receiving the benefits of such regulation. Yet it is important to stress that the equal protection primciple only inandates that similarly situated entities be treated equally. ${ }^{72}$ In fact, the principle of Equal Protection inay be violated when dissimilar people are treated similarly. ${ }^{73}$ Of course in applying this principle, much turns on what counts as a relevant similarity. ${ }^{74}$

The arguments of the previous Sections have suggested that dominant and fringe firms are dissimilar in terms of their competitive impact on an industry and that their dissimilarities provide a rational basis for disparate treatment. ${ }^{75}$ It is important to emphasize that the standard of scrutiny of the Constitution's Equal Protection Clause apphicable here is less stringent than it is for other regulations, such as those involving the "fundamental rights" of citizens. This is especially true with regard to the type of economic regulation at issue in this Article. Thus, a partialindustry regulatory scheine that makes distinctions based on the size or incuinbency of an industry's firms would most likely survive the modest scrutiny mandated by the Supreme Court's parsing of the Equal Protection Clause. ${ }^{76}$

Yet there may be times when the community would benefit froin applying dommant-firm or fringe-firm regulatory strategies to individual firms within a fairly hoinogeneous ohigopoly. In such oligopolies, com-

reasonable basis does not offend against [the Equal Protection Clause] merely because it is not made with mathematical nicety or because in practice it results in some imequality").

72. See Gerald Gunther, The Supreme Court, 1971 Term-Foreword: In Search of Evolving Doctrine on a Changing Court: A Model for a Newer Equal Protection, 86 HARV. L. REV. 1, 19-20 (1972) (discussing development of equal protection doctrine requiring only equal treatment of similarly situated groups).

73. See Laurence H. Tribe, American Constitutional Law § 16-1, at 1438 (2d ed. 1988) (equality can be demied when government fails to distimguish between persons who should be regarded differently for equal protection purposes).

74. For example, one could not treat people differently because their names were different unless their names were a legitimate characteristic upon which to distinguish treatment. See Joseph Tussman \& Jacobus tenBroek, The Equal Protection of the Laws, 37 CALIF. L. REv. 341,344 (1949) (determination of whether classification is reasonable because it includes all who are similarly situated depends on definition of "similarly situated"); see also Note, Legislative Purpose, Rationality, and Equal Protection, 82 YALE L.J. 123, 125 (1972) (discussing Supreme Court's rejection of drawing a statutory distinction between married and unmarried persons).

75. See supra notes $14-45$ and accompanying text (diseussing dominant-firm and fringe-firm theory).

76. See Vance v. Bradley, 440 U.S. 93, 109 (1979) ("We accept such imperfection because it is in turn rationally related to the secondary objective of legislative convenience."); TRIBE, supra note 72, $\S 16-2$, at 1440 ("[C]ourts have traditionally exhibited extreinc deferencc to the legislativc definition of 'the general good,' either out of judicial sympathy for the difficulties of the legislative process, or out of a belief in judicial restraint generally."). 
petitive advantages can still result from restraining the pricing of individual firms. The regulation is no longer rationalized on differences between the firms, however, and the very similarity of the firms imcreases their equitable claim when only one is subject to regulation. Regulators can respond to these equitable concerns in two ways without forfeiting the benefits of single-firm intervention. First, it may be possible to turn the government's choice of regulation into a tournament itself. If the government decides that it should restram the behavior of an individual firm within an oligopoly, for example by regulating the quality of its product, ${ }^{77}$ it might choose to single out the firm that has behaved least competitively in the past. Individual firms trying to avoid the price regulation conld then coinpete to avoid the regulatory constraint by pricing inore coinpetitively im the preregulation periods. Second, the government might randomly choose the firm that is to be the object of the price regulation in a given finite period, and different firms could be chosen im each successive period. As discussed above, ${ }^{78}$ such a decision rule would put the similar firms in the same ex ante position and, if viewed from this perspective, there would be no disparate treatment. ${ }^{79}$

The more substantive risk with this last decision rule is that firms would be singled out nonrandomly in a systematic effort to exclude them from the market. Regulators captured by certain firms im an industry might purposefully regulate other firms to put them at a competitive disadvantage. If individual firms could cause regulators to force their rivals to increase prices or undertake inefficient modes of production, then the regulated rivals could be effectively excluded from the market. Rather than fulfill their intended purpose of mitigating industry cartehzation, partial-industry regulations might imstead facilitate the raising of rivals' costs. ${ }^{80}$ Even more perniciously, regulators might threaten burdensome

77. See supra notes 53-55 and accompanying text (discussing government regulation of quality of oligopoly products).

78. See supra Part I.A.3 (discussing difference between ex ante and ex post intervention).

79. See supra Part I.A.3 (discussing tournament regulations applying disparate treatment ex post, at the end of play). A randoin-clioice rule seems outlandish but tax-auditing choices are, for example, often inade stocliastically. In calculating the faimess of random intervention one should distinguish between "equal proteetion" arguinents and "takings" arguments. Equal proteetion arguments focus on disparate treatment of the regulated and the unregulated. On the other liand, takings arguments would suggest that it is unfair to restram a regulated firm witlout just compensation irrespective of governments' treatment of competitors. It would be difficult to imagine that the government could be constramed on takings grounds from regulating a single firm when it could nonetheless regulate an entire industry. In this instance the greater takings power includes the smaller. Cf. Richard A. Epstein, The Supreme Court, 1987 Term-Foreword: Unconstitutional Conditions, State Power, and the Limits of Consent, 102 HARv. L. REv. 4, 8 \& n.11 (1988) (citing Posadas de Puerto Rico Assocs. v. Tourism Co., 478 U.S. 328, 345-47 (1986), for the proposition that the "greater" power to bar gambling also includes the "lesser" power to bar gambling advertisements).

80. See Steven C. Salop \& David T. Sclieffman, Raising Rivals' Costs, 73 AM. EcoN. REv. 267, 268 (1983) (discussing exclusionary practices having the effeet of raising rival's costs). 
regulation of individual firms as a way of extracting "rents" from competitors in an industry who wish to avoid these costs. 81 The appropriateness of partial-industry regulation would turn on the ability of society to control these deleterious forms of capture and rent seeking. While not rising to the level of a constitutional violation, the threat that government disparate treatment of economic persons could be capricious or malevolently enacted suggests that nonconstitutional equal protection concerns might remain.

In short there are no serious equal protection concerns with the two most important types of partial-imdustry regulation: dominant firms bearing the cost of regulation while less powerful frimge firms escape that cost, and weak, fringe firms receiving a benefit, which is denied to stronger competitors, keeping or brimging them into existence. In the case of regulatory costs being imposed selectively on equally inatched firms, however, equal protection concerns might need to be addressed. We have suggested tournainents, lotteries, and turn taking as equitable solutions to the problein of equal treatinent. These suggestions might be susceptible to capture and corruption, however, when regulator decisions involve selective placement of restrictions. Openness, accountability, and rights of appeal are vital measures to allow victimis of captured decisions a form of redress. The ineasure we favor for safeguarding against capture and corruption is the explicit involvement of representatives elected by consumer groups in the regulatory process. ${ }^{82}$

II

APPLICATIONS

The theories elaborated above have been impleinented to varying degrees in several regulatory contexts. In this Part we explore the actual and potential use of partial-industry regulation by examining in detail case studies in four industries: oil, airline service, news media, and longdistance telephone service.

\section{A. Destabilizing OPEC}

After thirteen years of successful collusion, the oil cartel of the Orgainzation of Petroleum Exporting Countries (OPEC) disintegrated in 1986. The cartel dissolved when price chiseling by individual member

81. See Fred S. McChesney, Rent Extraction and Rent Creation in the Economic Theory of Regulation, 16 J. LEGAL STUD. 101, 102-03 (1987) (arguing politicians can extract "rents" from private actors by threatening to impose burdensome restrictions on them unless a certain payment is met).

82. See AYRES \& BRAITHWATTE, supra note 6 (discussing delegation of regulator enforcement to third parties); Ian Ayres \& John Braithwaite, Tripartism: Regulatory Capture and Empowerment, 6 LAW \& Soc. INQUIRY 801, 807-10 (1991) (discussing tripartism policy). For a discussion of thirdparty regulatory participation, see the Conclusion of this Article. 
nations instigated a price war that more than halved the price of oil. The instability of OPEC was brought on in part by the downturn in Umited States deinand for oil. With reduced demand, some OPEC ineinbers could no longer stay within their OPEC production quota and still generate the revenues required for domestic programs. To increase revenues, the poorest oil-exporting nations began to cut the cartel price in an effort to regain soine lost deinand. ${ }^{83}$

In the wake of Iraq's unsuccessful invasion of Kuwait, OPEC may be on the verge of reestablishing its ability to control oil prices. ${ }^{84}$ The conditions for successful cartelization have improved: both Iraqi and Kuwaiti oil-production capacity have been limited by the war's destruction, and world deinand and consumption of oil has returned to higher pre-OPEC rates of growth. OPEC's recent success in forming agreements among ineinber nations for modest reductions in their production quotas might be the harbinger of a more disciplined cartel in the future. ${ }^{85}$

It is natural to ask whether the Uinited States, the primary importer of energy and consequently the primary victim of the OPEC cartel, could do anything to prevent the resurgence of a cartel that had disrupted the world economy for thirteen years. ${ }^{86}$ We argue that partial-industry intervention that exploits the inherent instability of cartels could achieve this objective. Individual ineinbers of OPEC have powerful incentives to violate OPEC's strict price and production limits. For example, by cutting price shightly a producer could sell inuch inore oil at a still highly inflated price. In deciding whether to engage in such price chiseling, OPEC ineinbers inust weigh the potential gains from price chiseling against the possibility of lost future profits if a price war ensues. If enough meinbers behieve the gains will outweigh the possible losses and therefore decide to chisel, the cartel will disintegrate.

The presence of even a few cartel chiselers can cut into the profits of the remaining members and thus drastically reduce the effectiveness of a cartel. As OPEC's experience in the 1980s suggests, price chiselers are by themselves very powerful destabilizing forces. When oil-exporting debtor nations, such as Nigeria and Libya, routinely began to lower their prices and exceed their production limits to increase their oil revenues, Saudi Arabia, the dominant OPEC producer, retaliated in kind by driv-

83. See generally Ayres, supra note 20, at 314-16 (1987) (sketching events leading to OPEC's collapse).

84. See Steven Greenhouse, Deal Set on OPEC Cut, but Not All Are Happy, N.Y. TiMEs, Mar. 13,1991 , at D1 (predicting that OPEC's agreement to cut oil production would push prices higher).

85. Moreover, OPEC-inember states might have lowered their domestic-revenue requirements after operating for inore than four years with depressed oil prices. See id.; $c f$. Stephen Koepp, "The Price War Is Here", TIME, Feb. 17, 1986, at 54 (discussing 1986 fall in OPEC prices after inember nations boosted oil production to increase revenues and satisfy donestic prograns).

86. A related inatter is whether the United States could have hastened OPEC's collapse in 1986. 
ing the price of oil to less than half the former level. ${ }^{87}$ But the history of OPEC also indicates that these incentives to chisel do not always preclude collusion. After all, the inherent instability of cartels did not keep OPEC from gouging oil consumers for inore than a decade, and it cannot insure competition in the future. Although the OPEC ministers seein now to be in disarray, there is no guarantee that a new Sheik Yamani will not forge another strong Arab alliance or that in the future demand will not agaim outstrip non-OPEC supply and force importers to coinply with cartel restrictions.

Partial-mdustry strategies, however, could have been used in the past and might be implemented in the future to undermine the ability of OPEC to raise oil price above production costs. These intervention strategies cannot take the form of direct regulatory fiat-as, for example, with dominant-firm price regulation-because one nation has no regulatory jurisdiction over the pricing decisions of other sovereign states. Structural mcentives directed at individual member states, however, might induce competitive behavior im the oil inarket. Simiply stated, the Umited States and its allies could destabilize OPEC by enhancing the already existing mcentives for imdividual producer nations to breach the OPEC agreement.

An optimal strategy of destabilization would employ a mixture of carrots and sticks to achieve this end. Offering a "carrot" in the form of debt forgiveness, favored-nation trading status, additional foreigu aid, or pronises of diplonnatic and military support in the event of attack to specific oil-producing nations could thus be conditioned on increased oil production. Linking badly needed econonnic-development loans and their refinancing to the betrayal of OPEC might be especially effective because the need for oil revenues to maintain existing debts had induced Nigeria and Venezuela to cheat the cartel in the first place. For years the International Monetary Fund has been conditioning loans on such factors as the borrower's fiscal deficit or money supply. ${ }^{88}$ Countries wishing to achieve OPEC destabilization could sinnly make monetary assistance dependent upon a different characteristic of the borrowing state: its oil production. Similarly, the United States could also induce coinpetition with the "stick" of threatening to withdraw necessary aid froin certain nations.

This form of partial-imdustry regulation-using incentives and penalties to change the behavior of OPEC meinbers-is soinewhat of a hybrid intervention strategy. It would employ fringe-firm techniques of

87. See Koepp, supra note 85.

88. See Philippines to Raise Taxes, Power Costs in Bid for Loans, ASIAN Wall St. J., Dec. 3, 1990, at 1, abstract available in LEXIS, Nexis Library, CURABS file (noting Philippine Government's efforts to reduce its deficit to secure International Monetary Fund loans). 
inducing firm action to reach an effect akin to dominant-firm price regulation because the goal would be to restrain the anticompetitive behavior of individual firms. Although the countries influenced by such policies might be relatively small producers, the combined effect of their actions could have the same weight as a similar action by a dominant country.

The example of OPEC is useful because it demonstrates the wide variety of policy options that could be available for implementing partialindustry regulatory strategies. The strategy suggested for OPEC is both feasible and cost-effective. The inefficiency of cartelization implies that consumers lose more than producers gain. Supracompetitive pricing produces a deadweight loss that represents this net social inefficiency. The gain to producers from cartelization is represented in Figure 2 below, by the area in rectangle 1. Supracompetitive pricing produces a deadweight loss, however, represented by triangle 2 , so that total consumer losses from cartelization equal the area in rectangle 1 and the deadweight loss in triangle 2. Thus, cartel pricing results in a net social mefficiency because this deadweight loss to consumers is not compensated by any

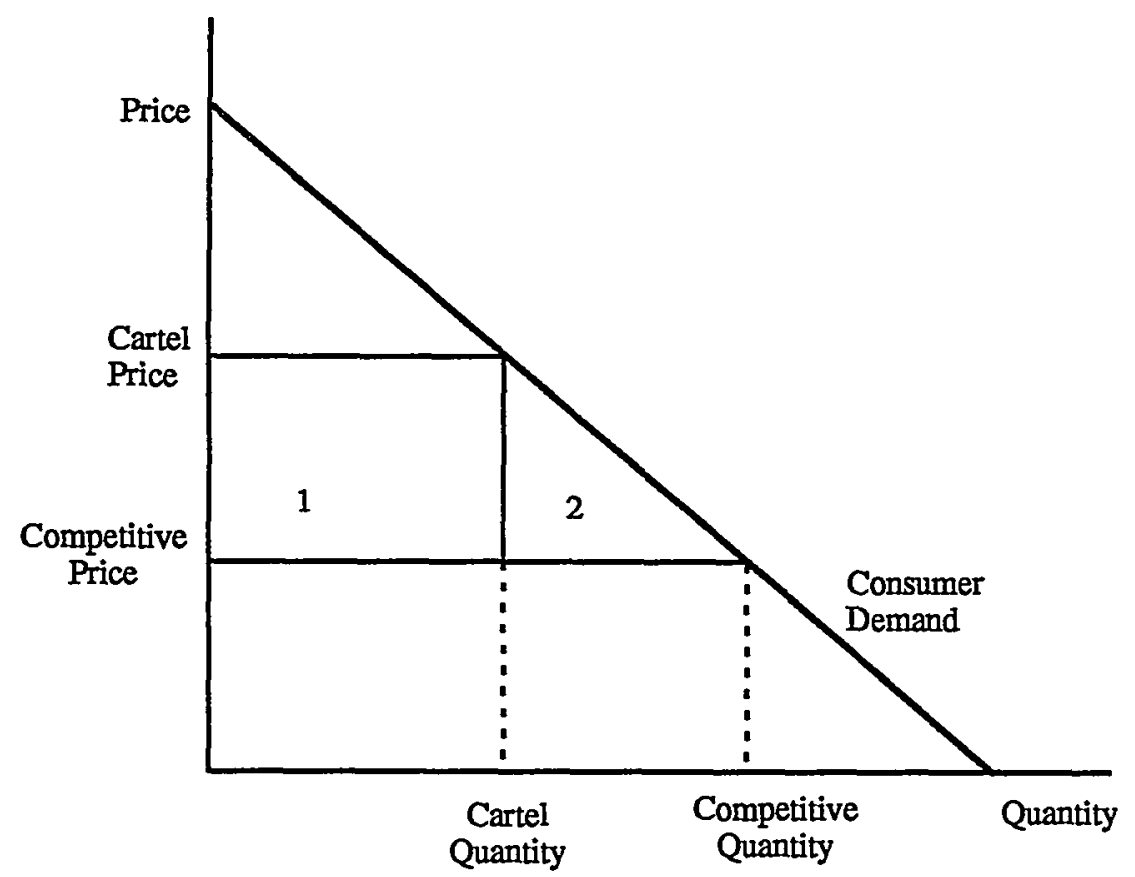

Area 1 = Cartel Profits

Area $2=$ Dead-weight Loss

Area $1+$ Area $2=$ Consumer Loss

(Potential size of bribe to increase output to competitive quantity)

FIGURE 2: The Possïbility of Efficient Cartel Bribes 
offsetting gain to producers. ${ }^{89}$

Theoretically, consumers could avoid the deadweight loss by paying a cartel a lump-suin bribe equal to the amount the producers would gain by producing only the cartel quantity in exchange for the cartel's agreement to produce the coinpetitive quantity. This is a theoretical possibility for all cartels but as noted in our discussion of second-sourcing subsidies ${ }^{90}$ the treinendous collective-action problems of such inultilateral agreeinents prevent diffuse oil consumers froin reaching this beneficial resnlt theinselves. The United States, however, is well positioned to overcoine the tendency of individual consumers to free ride on the bribery investinents of others. An efficiency bribe of this type would represent a kind of "industry-wide" intervention if the government negotiated a lunip-sum bribe to all of OPEC to increase its production..$^{91}$

Partial-industry strategies might, however, achieve the saine results as these industry-wide interventions at a fraction of the cost. By exploiting the inherent destabilizing incentives for cartel cheating, the United States government would not need to take on all of OPEC in order to inaintain competition in the oil niarket. As argued above, ${ }^{92}$ the presence of a sniall number of coinpetitive firms can have a dramatic procompetitive effect on a inarket. Thus, the United States might only need to pay a few OPEC nations to defect fron the cartel to result in conpetitive prices. Targeted destabilization might not even require the payment of a bribe: the threat of punishinent by the Uinted States, such as reduced credit or aid, could be just as effective as the promise of a bribe in encouraging individual countries to defect from OPEC production linits. Finally, the instability of OPEC in the 1980 s illustrated the willinguess of several nations to chisel even in the absence of targeted destabilization. These factors indicate that the size of the prizes or punishnients might not need to be great to induce individual countries to breach the cartel agreeinent. $^{93}$

89. See Richard A. Posner, ANTItrust Law: AN Economic Perspective 241-43 (1976).

90. See supra notes $39-45$ and accompanying text.

91. A potential difficulty with this scheme is that other oil consuming nations would benefit from the increased production along with the United States. It is uncertain whether the United States could persuade them to contribute their share of the "bribe" money. If not, an international free-rider problem would arise. In light of recent American success in seeuring contributions and cooperation for the Persian Gulf War from several industrial nations, such a problem might be surmountable. See John Barry, "Good to Go". NEwSwEEK, Feb. 18, 1991, at 26 (noting British and French participation in Gulf War offensive).

92. See supra notes $28-45$ and accompanying text (discussing fringe-firm interventions).

93. Indeed, in the framework of our model Iraq's August 1990 invasion of Kuwait and threatened invasion of Saudi Arabia can be seen as a form of partial-industry intervention aimed at shoring up oil prices. Saddam Hussein explicitly justified Iraq's action as a targeted punishment of Kuwait for violating its OPEC production quota. Moreover, the subsequent massing of Iraqi troops on the Saudi border has been interpreted as a threat designed to force Saudi Arabia to curtail its production. See Martin Sieff, Kuwait Invasion Prompts Little Saudi Response, WASH. Times, Aug. 
An overt policy of targeted destabilization might, however, have costs that go beyond the economic implementation of the regulation scheme. For example, partial-mdustry strategies might affect diplomatic relations with Middle Eastern states. Some people might criticize punishments that inequitably target certain third-world countries; others might disdain bribes as a type of ransom for economic terrorists. Moreover, the United States might have reasons for not wanting lower domestic oil prices available to consumers. ${ }^{94}$ Nevertheless, pohicy makers should at least realize that targeted partial-mdustry strategies could represent a powerful tool to ensure competitive oil prices.

If it were operated privately in the United States, the OPEC cartel would be a criminal conspiracy in restraint of trade under the Sherman Antitrust Act. ${ }^{95}$ Yet the United States' response to the cartel has been to attempt to hide from its effects by making itself less energy dependent. Reduced energy dependence is something we may mdependently wish to support to be more responsible global citizens. Energy independence, however, is an industry-wide response to threatened cartehization. The unregulated market provides strong incentives for price chiseling by cartel members that can eventually cause cartels to dismtegrate. But as OPEC has shown us, "eventually" can be a painfully expensive period. Partial-mdustry imtervention using targeted incentives that encourage individual nations to cut prices or mcrease output can move beyond a policy of blind faith in eventual cartel demise to a more rational tactic that encourages the undermining of OPEC and the promotion of competition.

\section{B. Bailing Out People Express}

In a 1986 decision that was consistent with the Reagan administration's lax antitrust enforcenent, the Justice Department's Antitrust Division approved the merger of People Express and Texas Air. ${ }^{96}$ People

6, 1990, at A8 (noting Iraqi military pressure on Saudi Arabia to change its production policy and support for this pressure in neighboring Arab nations hoping to raise oil prices).

94. There are, lowever, alternate methods of inaintaining the benefits of high oil prices that would allow the Unites States government to reap the rewards rather than OPEC. An import tariff on oil could protect domestic producers by allowing them to charge a price high enough to cover their higher costs of production without forgoing the benefits of lower OPEC prices. The United States government would retain those benefits through tariff revenues. Similarly, higher taxes on oil could continue to encourage energy conservation and its resulting environmental benefits while converting the deadweight loss of supracompetitive pricing into a tax benefit for the government.

95. "Every contract, combination in the form of trust or otherwise, or conspiracy, in restraint of trade or commerce anong the several States, or with foreign nations, is declared to be illegal." Sherman Act, 15 U.S.C. $\$ 1$ (1988). Even with the explicit involvement of foreign governments, such extraterritorial restraint on prices might fall within the Act's coverage. See id. §6a (setting forth a two-part test for deternining whether foreign conduct affecting United States trade or commerce violates the Slierman Act).

96. See Andy Pasztor \& William M. Carley, People Express Bid by Texas Air Clears a Hurdle, 
Express had been a price cutter, charging sometimes as little as a third of the going fare. People's presence in the airline industry had dramatically affected the nature of competition on the routes it served, forcing other airlines to engage im fierce price competition. After the loss of People Express as an mdependent inarket force, fare increases on the routes that People had serviced followed almost immediately, just as transatlantic fares increased after Sir Freddie Laker's financial demise.

The Clayton Act forbids inergers if their effect "may be substantially to lessen competition." trust pohicies, however, even the foreseeability of higher prices did not mean that the merger would lessen competition enough to be condemned. Approval of the People Express merger stemmed in part from the losses that People had been sustaining. The airline was classified as a failing firm ${ }^{98}$ that was likely to join its subsidiary Frontier in bankruptcy. The Justice Department reasoned that because People Express would be lost either through merger or bankruptcy, preventing the merger would not preserve competition. ${ }^{99}$

Regulatory choices, however, need not be this restrictive. The failing-firm doctrine is flawed because it does not seriously consider the benefits of fringe-firm intervention, which would have maintained People Express as an independent market force. This intervention might take any one of a number of forms, from a bailout to an outright purchase of the firm. Single-firm interventions that maintaim the existence of individual firms have occurred in the past-the bailout of Chrysler is a notable example. Past interventions of this sort have been primarily motivated by concerns for labor, such as in the case of the Amtrak bailout. Yet as discussed above, competitive concerns about the general welfare of consumers could also justify a bailout. As the experience of People Express illustrates, the contimued presence of a single price cutter can beneficially discipline an industry.

Single-firn intervention is by no means a panacea. One of the chief problems of such regulation would be to maintain the price-cutting conduct of the fringe firm after the bailout. But merely increasing the number of competitors can by itself undernine the ability of dominant firms to charge supracompetitive prices. ${ }^{100}$ When the prices in a inarket

WALL ST. J., Oct. 2, 1986, at A2 (reporting on the U.S. Department of Justice's clearing the purchase of People Express and Frontier Airlines by Texas Air).

97. Clayton Act, 15 U.S.C. $\S 18$ (1988).

98. Emery's Failing Finances Spur Approval of Merger, Aviation WK. \& SpaCe TeCH., Apr. 10, 1989, at 97.

99. See id. (under "failing firm doctrine" an anticompetitive acquisition is allowed if the acquired firm would otherwise be unable to meet its obligations and emerge as a viable competitor).

100. On the other hand, continuing subsidies might also undermine the incentives of regulated firms to undertake cost-saving ventures. Accordingly, government regulators should keep fringe firms in an industry only at costs that reflect efficient production. To ensure this efficiency, 
have been persistently and disproportionately high or when a merger is likely to generate such high prices, then taking over or subsidizing a failing firm that would serve as a price cutter might be the most effective method of promoting competition. Once again, we need not beheve that firm intervention is without cost, ${ }^{101}$ ouly that it is better than the alternatives of doing nothing or imtervening on a larger scale through divestiture or industry-wide regulation.

The previous analysis of second-sourcing refuted the claim that pubhic ownership of an individual firm falls outside the proper doinain of government action. In markets that have consistently failed to produce coinpetitive behavior, competition is itself a public good whose provision and preservation are within the classic scope of government action. When People Express cut prices to increase its sales, the resulting benefits did not inure to that airline alone: lower fares were paid by both People's passengers as well as the passengers of other airlines because of the People-inspired coinpetition within the industry. Thus, government subsidization of People Express could have paid big dividends to consumers in general by keeping all airline fares low.

The argument that People Express failed because it was inefficient and that subsidizing its future existence would only have prolonged this inefficiency ignores the realities of private second-sourcing. The essence of second-sourcing is a subsidy froin downstream firms to an upstream firm with high costs. The subsidy is designed to maintain a competitive presence in the upstream market. Not only is it a theoretical possibility that the inefficiency of maintaining a higher cost upstreain producer is outweighed by the increased competition in the upstream market, but the prevalence of second-sourcing by monopsomist buyers is strong evidence that the subsidization of failing firms can be efficient. IA markets without concentrated consumer demand, such as the oil and airline-service industries, government can be well positioned to act on the behalf of consuiners in inaking such a subsidy.

Competition could be fostered even further if the regulator exploited the very fact that single-firm subsidies discriminate against other firms in the industry. As argued in the previous Section, the government might

regulators might create tournaments among potential fringe firms to determine the least-cost subsidy.

While yearly subsidies should not exceed the social benefits they generate, it can be sound policy for the subsidies to be continuing. Returning to our analogy of private second-sourcing, see supra notes 58-70, it is important to note that some firms, such as General Motors, are willing to provide direct and indirect subsidies to their suppliers on an ongoing basis to retain second sources for inputs. Sinilarly, it can be advisable for government in comparable situations to regularly bail out failing yet competitive producers on behalf of the citizenry.

101. Nor must we deny that an important cost of bailing out failing firms is an erosion of market discipline. Further, we concede that initially efficient subsidies can be politically difficult to remove when they later become inefficient. 
purposefully create a tournament in which the firms in an industry coinpete agaimst each other for the privileged position. The subsidy could be awarded on the basis of competition itself, going to the largest price cutter ainong the competing firms. People Express easily met this standard. Creating a tournament that rewards price cutting could create drainatic incentives for firms to defect from collusive cartel arrangeinents. However, the current era of airline deregulation complicates the analysis. It is possible that the new threat of potential competition in the airline industry might keep the fares low on soine of People's former routes, reducing the need for a competitive presence. Nevertheless, study after study questions the hypothesis that airline routes are contestable- that entry is free and exit costless. ${ }^{102}$

People Express will not be the last price cutter to end in bankruptcy or merger. ${ }^{103}$ Price cutting is a risky business, and it may be socially desirable to provide soine insurance for this strategy in instances where consuiners would certainly benefit. While we do not argue that the government should frequently bail out failing firms, we do believe that competitive bailouts deserve reassessment. In the end one inight conclude that it is administratively too difficult for government regulators to identify the worthy recipients of an "efficiency" bailout. But the fact that private consumers are often willing to buy or subsidize failing upstreain suppliers is at least sufficient evidence to shift the burden to those who would dismiss such interventions out of hand.

A final, inore recent example that dramatizes the potential consumer benefits froin frimge-firm intervention involves a 1989 United States Supreme Court decision allowing the Detroit News and the Detroit Free Press to inerge. ${ }^{104}$ The two papers had previously been fierce competitors and had claimed losses in recent years. Industry analysts predicted, however, that the inerger, techmically called a "joint operating agreeinent," would ultimately generate profits for the two papers of up to $\$ 100$ million per year. In addition, by eliminating coinpetition the inerger almost certainly increased advertising rates in the city. Even if the Detroit newspaper inarket was a natural inonopoly, in the sense that two coinpetitive firms could not both recoup their fixed costs, it inight have been in the city's interest to subsidize one or both firms and

102. See, e.g., Ayres, supra note 37, at 197 (analysis rejects hypothesis that airline routes are contestable); Gregory D. Call \& Theodore E. Keeler, Airline Deregulation, Fares, and Market Behavior: Some Empirical Evidence, in ANALYTICAL STUDIES IN TRANSPORT Economics 221, 22325 (Andrew F. Daughety ed., 1986).

103. Since December of 1990, Continental, Pan Am, and Midway have filed for corporate reorganization. Midway Airlines Files for Bankruptcy Protection, Arlanta Const., Mar. 27, 1991, at B1.

104. See Linda Greenhouse, The Media Business: Linking of 2 Detroit Papers Upheld by Court in Tie Vote, N.Y. Times, Nov. 14, 1989, at D1 (discussing the Supreme Court's ruling allowing Detroit's two daily newspapers to merge). 
engender an unnatural duopoly. If the two firms were losing only $\$ 5$ or $\$ 10$ million a year, a subsidy of that size to maintain them both as viable competitors could have been cost justified if it would have ensured such benefits as more coinpetitive advertising and newspaper prices, greater einployee retention, and a more competitive marketplace for ideas. ${ }^{105}$

Again, the comparison with the observable second-sourcing practice of private downstream firms is compelling. If all the consumers of the Detroit newspapers (including advertisers) took the form of a single buyer, it is not difficult to imagine that this hypothetical monopsonist would be willing to pay a $\$ 10$ million subsidy to keep a second source of supply. It can be in consumers' interest to subsidize failing firms if the continued presence of these firms would significantly constrain supracompetitive pricing.

\section{The Disparate Treatment of Broadcast and Print Media}

While this Article has focused on regulatory strategies to constrain supracoinpetitive pricing, ${ }^{106}$ partial-industry imterventions could also enhance other aspects of an industry's performance. The current regulatory structure for the marketplace of ideas in the United States offers a striking example of partial-industry regulation in other contexts. ${ }^{107}$ In two seminal cases ${ }^{108}$ the Umited States Supreme Court established that the government may regulate the broadcast media in ways that would be unconstitutional if applied to the primt media. Specifically, these cases allowed the Federal Communications Commission (FCC) to impose "equal time" regulations on radio and television broadcasters and struck down the application of such regulations on newspapers. ${ }^{109}$ The Supreme Court based its disparate treatınent on its perception of the different technological capacities for multiple speech. The Court felt that

105. Since 1969 Sweden has undertaken such selective intervention strategies with continuing multimillion-dollar subsidies of newspapers to counteract further concentration of ownership and to facilitate the establishment of additional newspapers. See Robert Taylor, Birthday Party Answers Critics—Social Democracy Rules the Political System, but Less Comfortably, Fin. TIMES, Oct. 2, 1989, at 35 (state subsidies ensure survival of pluralistic media in Sweden).

106. See supra notes $12-51$ and accompanying text (discussing strategies designed to achieve competitive pricing).

107. Ian Ayres, Halfway Home: On Powe's American Broadcasting and the First Amendment, 13 LAw \& Soc. INQuiRx 413, 414-19 (1988) (book review) (discussing theories of broadcast regulation and their costs).

108. Compare Red Lion Broadcasting Co. v. FCC, 395 U.S. 367, 386-401 (1969) (finding FCC's imposition of a "fairness doctrine" on broadcasters consistent with the First Amendment) with Miami Herald Publishing Co. v. Tornillo, 418 U.S. 241, 258 (1974) (holding that the First Amendment prohibits "fairness doctrine"-type regulation of the press).

109. An example of one specific type of equal-time regulation that is cominonly referred to as the "fairness doctrine" requires "that discussion of public issues be presented on broadcast stations, and that each side of those issues must be given fair coverage." Red Lion Broadcasting, 359 U.S. at 369. 
the limited capacity of the broadcast media could justify regulations that would prevent these scarce sources from being dominated by one viewpoimt. However, similar regulations would not be appropriate for the print media because a vast number of speakers can communicate in print, so that this form of media is not susceptible to the kinds of domination that could cause the broadcast media to require regulation.

Many commentators have attacked the disparate Supreme Court treatment of these two main branches of the mass media. The Court's scarcity distinction has been roundly criticized by academics who have shown, for example, that the lack of economic opportunities for multiple newspapers im small towns can make the print media an even more difficult environment for multiple voices. Some commentators, perceiving no significant difference between the two types of media, have argued for imdustry-wide regulation; ${ }^{10}$ others, perceiving no difference, have argued for laissez-faire policies. ${ }^{111}$

Lee Bollinger, however, has proposed an innovative theory that offers a positive justification for disparate treatment of print and broadcast media. While acknowledging that these two forms of media are similar, he nonetheless suggested that adopting a strategy of partial-industry regulation differentiating between the medias could be advantageous. ${ }^{112}$ In an article (which is suggestively subtitled Toward a Theory of Partial Regulation of the Mass Media) Bollinger presented the provocative theory that "the very similarity of the two major branches of the mass media provides a rationale for treating thein differently."113 Lucas Powe summarized Bollinger's thesis:

The separation of broadcasting from print provides the nation with "the best of two worlds": "access in a highly concentrated press and minimal government intervention." Access and balance are important goals, but governmental regulation always brings with it the risks of censorship, either private or public. The fact that print is unrestrained, however, provides a check on those risks: information not disseminated by broadcasters will be available in newspapers, and the very existence of an unregulated press will provide a competitive spur to offset any tendency of broadcasters to be excessively timid. ${ }^{14}$

110. See, e.g., Jerome A. Barron, Access to the Press-A New First Amendment Right, 80 HaRv. L. REV. 1641 (1967) (finding distinction between press and inedia dubious and calling for regulation of access to the press).

111. See, e.g., Lucas A. Powe, Jr., American Broadcasting and the First AMENDMENT 248-56 (1987) (arguing that First Amendment doctrine accommodates freedom from government regulation for both broadcast and press media).

112. Lee C. Bollinger, Jr., Freedom of the Press and Public Access: Toward a Theory of Partial Regulation of the Mass Media, $75 \mathrm{MICH}$. L. REV. 1 (1976).

113. Id. at 36 .

114. Powe, supra note 111 , at 5 (quoting Bollinger, supra note 112, at 27,36 (footnotes omitted)); see also Ayres, supra note 107, at 416 (noting Powe's agreement with Bollinger's thesis that the two forms of media have no relevant constitutional distinction). 
Bollinger's apology for the disparate treatment of print and broadcast speech is strikingly similar to this Article's preceding arguments for partial-industry regulation. His theory is a form of dominant-firm intervention that leaves the competitive fringe unregulated. The regulated and unregulated portions of an industry can create a system of mutual cliecks and balances. When this strategy is apphed in the marketplaceof-ideas context, both the governinent-regulated portion and the laissezfaire portion check each other for potential abuses, providing a coinpetitive backstop for a society that does not know which mechanism for market organization (public or private) to trust.

\section{Dominant-Firm Regulation of Long-Distance Telephone Service}

The success of dominant-firm intervention in the United States longdistance telephone industry argues for considering its apphication in otlier regulatory settings. Dominant-firm regulation currently governs the Umited States long-distance telephone industry. Under the present regulatory regime, only the dominant firm, AT\&T, must subimit its rates to tlie FCC for approval. ${ }^{115}$ Fringe long-distance firms, such as MCI and Sprint, are not subject to minimuin-price rules. ${ }^{116}$ As illustrated above, ${ }^{117}$ the inaximum-price rules regulating AT\&T constrain all firms within the industry from engaging in supracoinpetitive pricing.

In addition the minimum-price aspects of rate regulation also restrain the dominant firm froin price cutting aimed at excluding its new coinpetitors froin the market. Moreover, partial-industry regulation can achieve both these goals without forgoing the price-cutting fringe's disciphining effects on the dominant firm. The coinpetitive influence of fringe firms in the long-distance telephone industry was vividly illustrated one month after MCI announced plans for nationwide long-distance service in selected cities, when AT\&T sought permission to lower its long-distance rates in inany of those cities. ${ }^{118}$

115. See In re Policy and Rules Concerning Rates for Competitive Common Carrier Services and Facilities Authorizatious Therefor: First Report and Order, 85 F.C.C.2d 1, 22-24 (1980) (detailing and justifying restraints on AT\&T). For a discussion of tle FCC proceedings, see MCI Telecommumications Corp. v. FCC, 765 F.2d 1186, 1187-89 (D.C. Cir. 1985).

116. See In re Policy and Rules Concerning Rates for Competitive Common Carrier Services and Facilities Autlorizations Therefor: Fourth Report and Order, 95 F.C.C.2d 554, 578-79 (1983) (granting GTE Sprint an exception from regulations).

117. See supra note 14 and accompanying text (discussing effect of dommant-firm price constraiuts on fringe-firm pricing).

118. See Sydney Sliaw, AT\&T Asks FCC for Deregulation, UPI, Apr. 2, 1984, available in LEXIS, Nexis Library, UPI File (AT\&T's request for deregulatiou iu the long-distance teleplione industry to allow it to compete witl its rivals and offer lower prices). 


\section{CONCLUSION}

This Article has argued that partial-industry intervention is potentially superior to both industry-wide regulation and laissez-faire policies. While partial-industry regulation can take a wide variety of forms, this Article discussed three types of intervention strategy. First, "dominantfirm" strategies seek to restrain the anticompetitive behavior of dominant firms while leaving fringe firms unregulated. Second, "fringe-firm" strategies seek to promote or preserve the existence of fringe firns but allow the structurally improved market to set its own price. Finally, "oligopoly touruament" strategies seek to reward firms for their relative perforinance, as with patent races and yardstick competition.

These strategies might be used separately or in conjunction with each other to enhance the competitive environmént of an industry. For example, a partial-imdustry regulation bailing out People Express could have employed two strategies: conditioning the subsidy on sustaining People as a price cutter is a typical fringe-firn strategy, but the constraining influence of this condition on the larger firms also resembles a dominant-firm price restraint. One could also hypothesize a scenario employing all three strategies: (1) dominant firms must submit their prices for approval, (2) a fringe firn gets a tax break for research-anddevelopment expenditure, and (3) this tax break is targeted to the fringe firm with the best record of developing innovations that open new export markets. Doininant- and frimge-firm imtervention can also apply disparate regulatory processes to firms within an industry to encourage thein to investigate, promulgate, and enforce regulatory standards. For example, regulators could mandate that dominant firıns undertake special prograins of self-regulation. ${ }^{119}$

Partial-industry regulations can also empower third parties to participate in the regulatory process. An imcipient form of this latter, tripartite intervention strategy has been adopted in the British telecommunication industry-individual firms have been required by their national governments to consult with Consumer Councils. ${ }^{120}$ An approximation to fringe-firm strategies, tripartite intervention has also occurred with nursing-home regulation. Consumers have little market

119. Dominant-firm intervention might also take the form of what we have called "enforced self-regulation." See AYRES \& BRATTHWAITE, supra note 6. Enforced self-regulation consists of regulatory requirements for firms to prounulgate self-regulating rules and for government to verify that these rules are adequate and enforced. Under such a scheme a doininant-firm intervention version of enforced self-regulation would require the dominant firm to write rules to restrain monopoly abuse, and these rules would then be publicly approved. The dominant firm would be required to establish its own internal enforcement mechanisms to sustain compliance with those rules; this self-enforcement would be reinforced by public enforcement of the privately written rules.

120. See, e.g., Mary Fagan, BT Tariffs 'Penalise Poorest,' IndePendent, Feb. 18, 1991, at 6 (reporting the National Consumer Council's demand of an overhaul of British Telecom's pricing system). 
power in that industry; they are mostly too frail to "vote with their feet" by leaving the nursing home. An alternative method of securing consumer sovereignty and influence over the industry utilizes a fringe-firm, tripartite intervention strategy that encourages consuiner participation on Residents' and Relatives' Councils. The way regulators have historically sought to achieve this goal in Australia and the United States has been to encourage fringe firms to innovate by adopting such consumer participation groups. The state of Michigan, for example, paid bonus Medicaid rates to nursing homes that established effective Residents' Councils. ${ }^{121}$ The more immediate result of this strategy in both countries was the establishment of Residents' Councils within fringe firms as an emblem of high standards. The larger nursing-hoine chains then decided that they too wanted this reputational emblem worn by the fringe innovators. Now nursing homes lacking a Residents' Council are regarded as having low standards. ${ }^{122}$

Our proposal that partial-industry regulation be studied as a plausible regulatory alternative draws some support from both sides of the deregulation debate. For conservatives who are fighting industry-wide regulation, partial-industry regulation is less interventionist. For social democrats trying to overcoine laissez-faire niarket failure, it offers a public check on private actions. Indeed, the pohitical lines of support for partial-industry strategies will often be drawn in response to the current regulatory benchmark. If the benchmark is industry-wide regnlation, conservatives are likely to argue that partial-industry regulation is "niarket compatible." On the other hand, if the benchinark is deregulation, these same conservatives will characterize partial-industry regulation as anathema. A similar "shoe on a different foot" phenomenon will likely apply to the response from the left. We suspect, however, that there are cases in which consumer groups on the left and industry on the right will be willing to make a deal, avoiding the worst excesses of both industrywide regulation and the anticompetitive abuses of unrestrained laissezfaire market governance. In some situations, partial-industry regulation will be superior to either full regulation or laissez faire—and will leave both sides better off than the status quo.

In this Article we have argued that beneficial partial-nidustry regulation is plausible. This plausibility is bolstered not only by a handful of instances in which such regulations are already used ${ }^{123}$ but also by the

121. John Braithwaite, Australian National University International Nursing Hone Research (1989) (unpublished field notes, on file with the author) (survey of nursing home practices in 25 states of the United States and in 3 other countries).

122. Id.

123. See supra notes 104-16 and accompanying text (discussing curr $3 n$ dominant-firm regulation of news media and long-distance telephone service in the United States and fringe-firm intervention through newspaper subsidies in Sweden). 
private targeted use of analogous strategies by monopsonists. A government interested in acting on behalf of its consumer constituents should begin the job by studying and at times emulating the practices of these quintessentially empowered consumers. Our message is that if those consumers with market power protect themselves through strategies such as second-sourcing, we should consider government second-sourcing on behalf of less powerful consumers. The behavior of monopsonists can also provide a limiting principle on such use of government power: in situations where it would not be efficient for a private monopsonist to second-source, then the government should not intervene either. More circumspectly, we have argued that while meetimg the monopsony standard should be a necessary condition to government partial-imdustry regulation, it is not a sufficient condition for such intervention.

Although we have maintained that partial-industry regulation imposes lower inforination demands on government regulators than does industry-wide price regulation, ${ }^{124}$ the informational requirenents of any form of econoimc regulation are considerable enough to caution against most bureaucratic participation. Hence, we would not counsel even the mere consideration of partial-imdustry regulation for run-of-the-mill commodities. It should be considered only im markets that are so fundamental to the infrastructure of the economy-such as the energy, transportation, and telecommumications imdustries-as to justify concerted study of the risks and information costs of regulatory intervention. Moreover, there are special reasons to contemplate partial-industry regulatory strategies with the media: the econormic significance of the media is compounded by its importance to democratic freedoms in averting monopolization of the markets for ideas and news.

The history of economic thought since Keynes has seen a period of emphasis on the need for government correction of inarket failure followed by a period of emphasis on government's failure in its efforts to correct market failures. Public-choice theorists, for example, have argued that government intervention can produce outcomes worse than failed markets. Today the economic-pohicy debate proceeds as a battle between those on the left who want government regulation to correct market failures and those on the right who think that incompetence, agency capture, and corruption make government ill-equipped for industry regulation.

In terms of our analysis this is a debate between those who favor regulatory "shotguns" and those who advocate no guns at all. We contend that by selecting the proper regulatory rifle, it is theoretically possible to restrain the private exploitation of monopoly power without substituting the public exploitation of capture and bureaucratic empire

124. See supra note 45 and accompanying text. 
building. Partial-industry regulation uses public regulation as a clieck on private monopoly power and private competition as a balance against regulatory capture and error. Government is restrained from actimg as a cartel ringleader by the competitive forces of the unregulated firms competing with those that are regulated. If the government errs in controlling the price or facilitating the survival of the regulated firm, the error may not be fatal to the entire industry because it will not affect the unregulated firms in the market.

The insight of the partial-regulation idea is that it does not require a choice between siding witli the regulators or the deregulators. Creative pohicy design can incorporate botl1 approaches, utilizing the strengths of each strategy as a safeguard against the weaknesses of the otlier. 
